\title{
1. GEOTHERMAL PHENOMENA AT THE COSTA RICA RIFT: BACKGROUND AND OBJECTIVES FOR DRILLING AT DEEP SEA DRILLING PROJECT SITES 501, 504, AND 5051
}

\author{
M. G. Langseth, Lamont-Doherty Geological Observatory, Palisades, New York \\ J. R. Cann, The University, Newcastle-upon-Tyne NE1 7RU, United Kingdom \\ J. H. Natland, Scripps Institution of Oceanography, La Jolla, California \\ and \\ M. Hobart, Lamont-Doherty Geological Observatory, Palisades, New York
}

\section{INTRODUCTION}

These initial reports present the results of drilling and downhole experiments conducted at Sites 501, 504, and 505 , which are on the south flank of the Costa Rica Rift (Fig. 1). The sites were drilled during Deep Sea Drilling Project Leg 69 and parts of Legs 68 and 70 . The purpose of the drilling was to investigate geothermal phenomena in basaltic basement and overlying sediments at two locations in the same segment of an oceanic spreading center-the Costa Rica Rift. Site survey data, which are summarized in this chapter, led us to expect the sites to have sharply contrasting geothermal characteristics and degrees of alteration in basement.

One target, Site 505, was on crust about 3.9 m.y. old in an area of relatively high basement relief and low heat flow (Fig. 2). Three holes were drilled at Site 505 (Table 1). In the first hole drilled (Hole 505), sediments totaling 234 meters in thickness were continuously cored, but basement drilling proved difficult, and the hole had to be abandoned. At Hole 505A, the drill was washed to a shallower basement, but penetration was equally difficult. At the third hole, Hole 505B, 42 meters of basement were drilled with difficulty, but this depth was sufficient to allow logging.

The second target was due south of Site 505, in an area of high but uniform heat flow (Fig. 2) and little basement relief. The age of the basement here, as estimated by magnetic anomalies, is $5.9 \mathrm{~m}$.y. One hole was drilled at Site 501 and four holes were drilled at Site 504 (Table 1). Hole 501, which was drilled during Leg 68, was designed as the pilot hole for reentry. Because the sediments were to be cored continuously later, only nine cores were taken in the sediments in Hole 501. Basement was cored for 73 meters, and downhole measurements and experiments were made. Because it was necessary at this point for the Glomar Challenger to be drydocked, and because in the interim a new leg was arranged around paleoenvironmental objectives at Sites 502 and 503, the Costa Rica Rift drilling was not resumed for nearly 2 months. Then, during Leg 69, three holes were drilled at a new site (Site 504), which was a few hundred

\footnotetext{
ICann, J. R., Langseth, M. G., Honnorez, J., Von Herzen, R. P., White, S. M., et al., Init. Repts. DSDP, 69: Washington (U.S. Govt. Printing Office).
}

meters east of Site 501. In Hole 504, the newly developed hydraulic piston corer was used, and 237 meters of sediments were obtained in an essentially undisturbed condition. The remaining 27 meters of sediments above basement, which were too indurated for hydraulic piston coring, had been cored at Site 501. Hole 504A was the first attempt at establishing a reentry hole, but after only a few meters of basement were drilled the core bit broke into fragments in the hole. Hole 504B became a successful reentry hole. Basement penetration reached 214 meters during Leg 69 , and when drilling continued 40 days later on Leg 70 it reached 561.5 meters. On Leg 83 renewed drilling reached a depth of 1075.5 meters into basement.

The chapters in this volume are concerned with the drilling through Leg 70 .

Drilling was only part of the scientific program at the Costa Rica Rift. The chemistry of the interstitial waters was extensively investigated to evaluate reactions within the sediments and the influence of the formation of secondary minerals in the basement. Pore fluids were sampled in situ from the sediments, squeezed from the sediments, and for the first time drawn from igneous basement (Hole 504B) by using special sampling tools.

Records of various kinds of downhole measurements were made at all three sites, including conventional logs (caliper, sonic velocity, porosity, natural gamma radiation, density, resistivity, and temperature), magnetic logs, and an acoustic impression of the walls of the hole, which was acquired with a borehole televiewer. This was the first time that either the downhole magnetometer or the televiewer was used successfully in the deep ocean.

Another first was the in situ measurement of the permeability of basaltic basement. The measurements were made with a single element hydraulic packer inflated to seal off the hole. The rate of decay of a pumped pressure pulse was used to calculate permeability.

In addition to acquiring repeated temperature logs of the completed holes, temperature measurements were made at several points in the undisturbed sediments at Holes $501,504 \mathrm{C}$, and 505 by using the Tokyo/DSDP $\mathrm{T}$-probe. In Hole $504 \mathrm{C}$, only temperature measurements were made and in situ pore water samples taken; no cores were taken. The return to Hole 504B during Leg 70 was particularly valuable in that the hole had re- 


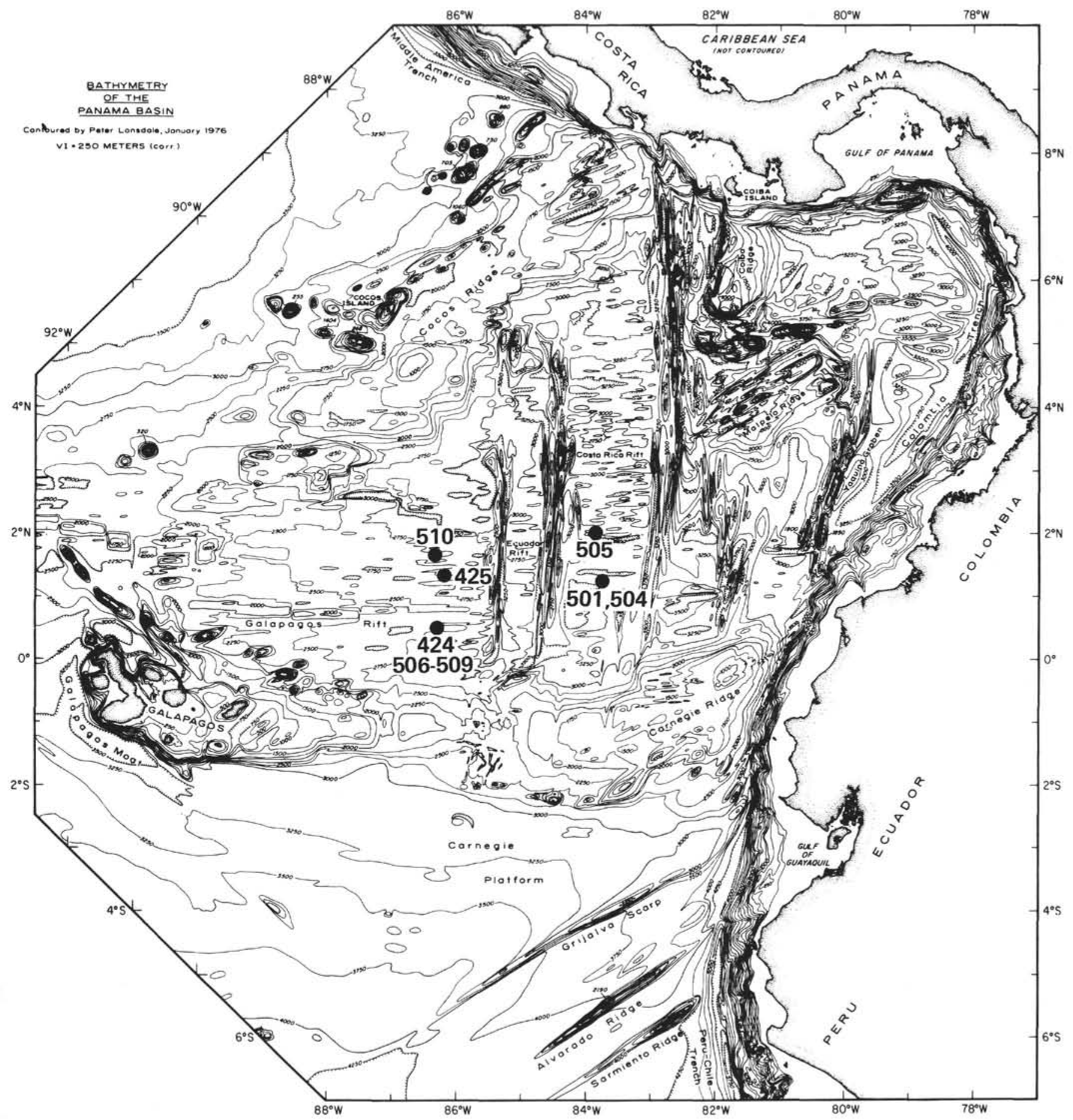

Figure 1. Location of Sites 501, 504, and 505, drilled during Legs 68, 69, and 70 near the Costa Rica Rift. Bathymetry from Lonsdale and Klitgord (1978). Also shown are the locations of Sites 424 and 425, drilled during Leg 54 (Rosendahl, Hekinian, et al., 1980), and Sites 506 to 510, drilled during Leg 70 (Honnorez, Von Herzen, et al., in press).

mained undisturbed for $\mathbf{4 0}$ days, so that the temperature measurements directly indicated near-equilibrium geothermal and hydrologic conditions in the hole and surrounding crust.

Two additional experiments were conducted in Hole 504B to measure the bulk properties of the ocean crust: the large-scale resistivity experiment and the oblique seismic experiment.
The results of all these activities are reported and interpreted in subsequent chapters of this volume. In this chapter, we provide the scientific context for the drilling that was provided by earlier geothermal investigations in the Panama Basin. We also present the results of a site survey cruise that was undertaken in 1978, on which one of us (M. G. L.) acted as Chief Scientist. The next two sections of this chapter describe the organization of 

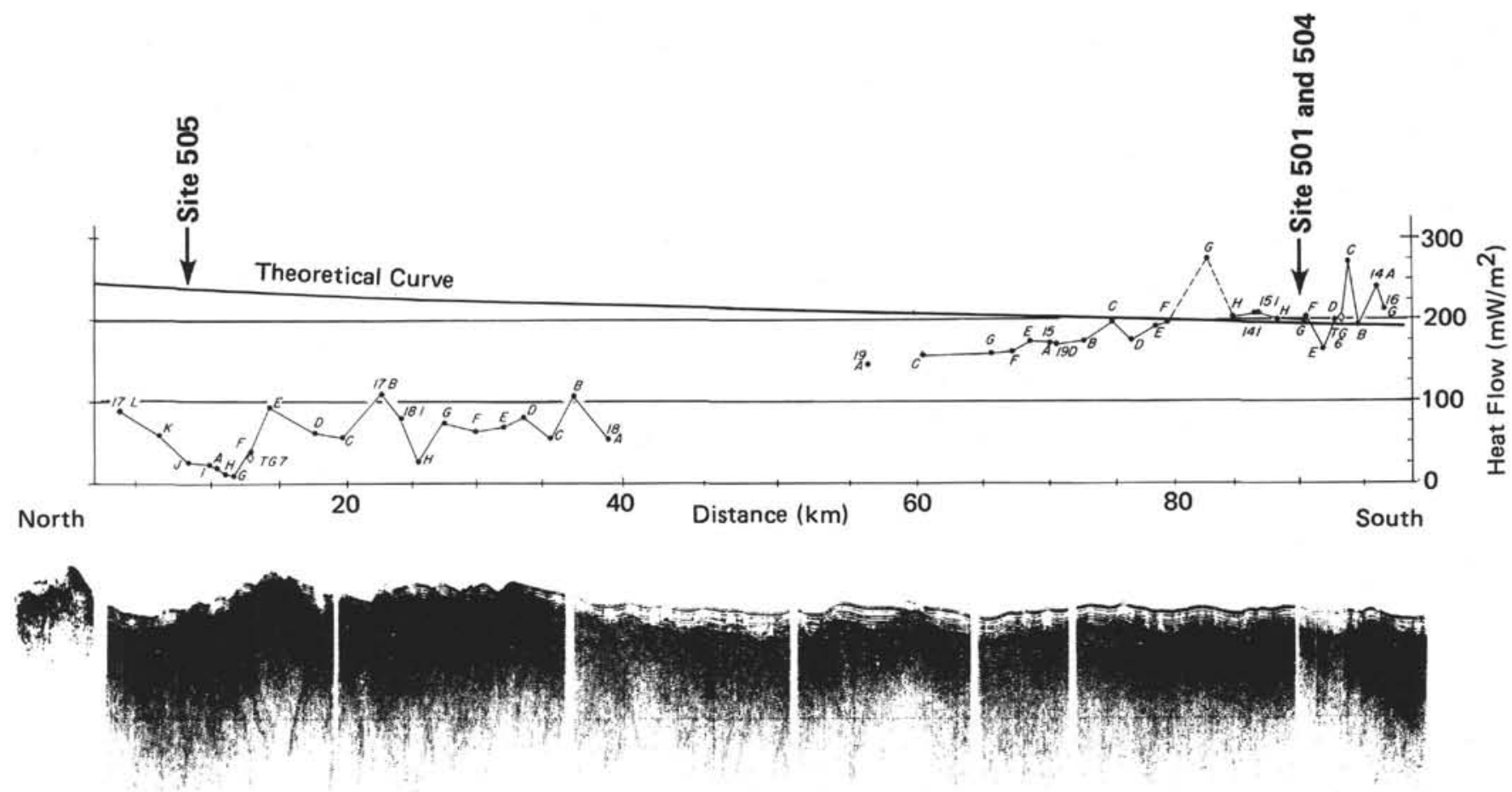

Figure 2. North-south profile of heat flow $\left(\mathrm{mW} / \mathrm{m}^{2}\right)$ plotted as a function of distance from the north end of the survey area. The Costa Rica Rift axis is off the figure to left. The heat flow profile is above a similarly scaled single-channel seismic record showing basement topography and sediment thickness. Alphanumeric designations identify the location of heat flow measurements (see Fig. 4). Locations of Sites 501, 504 , and 505 are shown.

Table 1. Coring summary.

\begin{tabular}{|c|c|c|c|c|c|c|c|c|c|}
\hline Leg & Hole & Dates (1979) & $\begin{array}{l}\text { Latitude, } \\
\text { Longitude }\end{array}$ & $\begin{array}{l}\text { Water } \\
\text { Depth } \\
\text { (m) }\end{array}$ & $\begin{array}{l}\text { Penetration } \\
\text { (m) }\end{array}$ & $\begin{array}{c}\text { Number } \\
\text { of } \\
\text { Cores }\end{array}$ & $\begin{array}{l}\text { Number } \\
\text { of } \\
\text { Meters } \\
\text { Cored }\end{array}$ & $\begin{array}{c}\text { Number } \\
\text { of } \\
\text { Meters } \\
\text { Recovered }\end{array}$ & $\begin{array}{c}\text { Recovery } \\
(\%)\end{array}$ \\
\hline 68 & 501 & 8-16 July & $\begin{array}{l}1^{\circ} 13.63^{\prime} \mathrm{N}, \dot{ } \\
83^{\circ} 44.06^{\prime} \mathrm{W}\end{array}$ & 3467 & 337.1 & 20 & 147.2 & 74.53 & 50.6 \\
\hline 69 & 504 & 20-23 September & $\begin{array}{l}1^{\circ} 13.6^{\prime} \mathrm{N}, \\
83^{\circ} 43.9^{\prime} \mathrm{W}\end{array}$ & 3470 & 237.0 & 54 & 227 & 176 & 76 \\
\hline 69 & 504A & 24-29 September & $\begin{array}{l}1^{\circ} 13.61^{\prime} \mathrm{N}, \dot{ } \\
83^{\circ} 43.95^{\prime} \mathrm{W}\end{array}$ & 3468 & 277.0 & 7 & 70.5 & 9.0 & 20.5 \\
\hline 69 & 505 & $\begin{array}{l}29 \text { September- } \\
1 \text { October }\end{array}$ & $\begin{array}{l}1^{\circ} 54.82^{\prime} \mathrm{N}_{1} \\
83^{\circ} 47.39^{\prime} \mathrm{W}\end{array}$ & 3547 & 242.0 & 26 & 223 & 187 & 72 \\
\hline 69 & 505A & 2 October & $\begin{array}{l}1^{\circ} 55.08^{\prime} \mathrm{N}, \\
83^{\circ} 47.35^{\prime} \mathrm{W}\end{array}$ & 3535 & 208.5 & 2 & 12 & 0.75 & 6.3 \\
\hline 69 & 505B & 3-7 October & $\begin{array}{l}1^{\circ} 55.177^{\prime} \mathrm{N}, \\
83^{\circ} 47.29^{\prime} \mathrm{W}\end{array}$ & 3517 & 178.0 & 6 & 42 & 6.9 & 16.3 \\
\hline 69 & 504B & 7-25 October & $\begin{array}{l}1^{\circ} 13.63^{\prime} \mathrm{N}, \\
83^{\circ} 43.81^{\prime} \mathrm{W}\end{array}$ & 3470 & $489.0^{\mathrm{a}}$ & 29 & 227.5 & 76.7 & 33.6 \\
\hline 70 & $504 \mathrm{~B}$ & 4-13 December & $\begin{array}{l}1^{\circ} 13.63^{\prime} \mathrm{N}, \dot{ } \\
83^{\circ} 43.81^{\prime} \mathrm{W}\end{array}$ & 3470 & $347.0^{\mathrm{b}}$ & 40 & 347.0 & 92.7 & 26.4 \\
\hline
\end{tabular}

a 214 meters in basalt.
b Total basalt penetration in Hole 504B: $561.5 \mathrm{~m}$.

the volume and the site chapters, and the appendix provides an explanation of the coring procedures, conventions, and notation used to describe the sediment and basalt.

\section{PREVIOUS GEOTHERMAL INVESTIGATIONS OF THE PANAMA BASIN}

The Panama Basin is one of the most extensively studied regions of the seafloor, containing within it many features of interest to marine geophysicists, geologists, sedimentologists, petrologists, and physical oceanographers. Much of the research has focused on geothermal phenomena on and near the actively spreading ridges in the
Panama Basin-the Galapagos, Ecuador, and Costa Rica Rifts, which together comprise the Galapagos Spreading Center (Lonsdale and Klitgord, 1978). An early deeptow study of near-bottom bathymetry and magnetic anomalies (Klitgord et al., 1975) indicated the existence of hydrothermal vents and mounds at $85^{\circ} \mathrm{W}$ between 17 and $21 \mathrm{~km}$ south of the Galapagos Rift. These and the Galapagos Rift itself were investigated for geothermal phenomena on several subsequent cruises, which saw the acquisition of deep-tow (Lonsdale, 1977) and submersible observations, plus heat flow measurements and core and dredge samples (e.g., Corliss, Dymond, et al., 1979). Later the mounds area was investigated by deep 
sea drilling (Rosendahl, Hekinian et al., 1980: Honnorez, Von Herzen, et al., in press). All these studies were focused mainly on convective geothermal systems in the ocean crust. Those at the rift axis provided evidence for the circulation and venting of high-temperature solutions that were heated by magma injected in the process of crustal accretion at the spreading center itself (Corliss, Gordon, et al., 1979). Studies made in the mounds area were related to the establishment of regular patterns of convecting fluids near consolidated, but nevertheless still quite warm, young ocean lithosphere (e.g., Williams et al., 1979; Hekinian et al., 1980; Green et al., 1981).

There were fewer earlier studies of the Costa Rica Rift, but one of particular importance was the determination by Anderson and Hobart (1976) that about $200 \mathrm{~km}$ south of the rift, sediment thickness was sufficient $(\sim 250 \mathrm{~m})$ to prevent almost all exchange of seawater between the ocean and the underlying basaltic crust. All of the heat from the cooling lithosphere must flow conductively through the sediment.

Drilling undertaken during Leg 54 (Rosendahl, Hekinian et al., 1980) was of special importance to the formulation of the drilling carried out during Legs 68,69 , 70 , and 83 in that it provided modest but nevertheless tangible evidence that deep crustal penetration was possible in the young basalts in the Panama Basin provided that geothermal processes had altered and cemented the hole walls sufficiently to prevent basalt fragments from falling into the hole, which had so often jammed the bit and created high torque in previous drilling (Natland and Rosendahl, 1980).

With these incentives on young ocean crust, the JOIDES Ocean Crust Panel and Planning Committee designed a two-leg program to investigate the wide variety of geothermal regimes accessible to drilling in the Panama Basin. Most of one leg was to be spent investigating the area of the Galapagos Mounds that was drilled during Leg 54, only this time a battery of new tools would be used, including the hydraulic piston corer and the Tokyo/DSDP T-probe (a downhole temperature-measuring device and water sampler). Shipboard laboratory programs would be designed around the special needs of a program devoted to the investigation of geothermal phenomena. This drilling took place during Leg 70 and is the subject of Volume 70 of the Initial Reports (Honnorez, Von Herzen, et al., in press).

The drilling program that is the focus of this volume was undertaken to investigate a region of contrasting geothermal and hydrological regimes in relatively young oceanic crust (3.9-5.9 m.y. old). In the northern part of the region numerous outcrops of basement permit the free circulation of seawater through the upper crust, keeping the basement at relatively low temperatures. This type of thermal regime is common along the relatively young flanks of mid-ocean ridges (e.g., Lister, 1972; Hyndman et al., 1977). One hundred kilometers to the south the ocean basement is almost completely covered by a 250 - to 300 -meter layer of sediment that caps the crust with an impermeable blanket and prevents the direct exchange between bottom water and basement pore water. Here, as mentioned earlier, all of the heat from the cooling lithosphere must flow conductively through the sediment (Anderson and Hobart, 1976). The level of flux is about $200 \mathrm{~mW} / \mathrm{m}^{2}$, which results in a temperature drop of 50 to $60^{\circ} \mathrm{C}$ across the sedimentary layer. The relatively high temperatures in the crust promote the alteration of the igneous basaltic rocks and the cementation of fractures. This type of thermal regime, which is found where high sedimentation rates lead to the fast burial of basement topography, is rare. One of the major objectives of the program was to drill into basement in a young high temperature crust.

As the first stage in the program, a site survey cruise was undertaken to investigate the region south of the Costa Rica Rift. Magnetic anomalies in this region indicated the presence of crust as old as Miocene, the time of the earliest movement along the presently active rifts in the Panama Basin (i.e., movement free of the disturbing effects of ridge crest jumps or rift propagation; see Hey, 1977; Hey and Vogt, 1977). The objectives of the site survey cruise were to determine whether and where in the Panama Basin a conductive geothermal gradient existed and, if such a gradient was located, to provide the geophysical information necessary to select drilling sites. The results of the site survey cruise are outlined below.

\section{THE COSTA RICA RIFT SITE SURVEY}

The predrilling geophysical survey was carried out on the R/V Conrad in a region over the flank of the Costa Rica Rift. Most of the work was between $1^{\circ}$ and $2^{\circ} \mathrm{N}$ and $83^{\circ} 30^{\prime}$ and $84^{\circ} 10^{\prime} \mathrm{W}$ (see Fig. 3). Along nearly all of the track lines shown, measurements were made of seafloor depth, the total intensity of the magnetic field, gravity, sediment thickness, and acoustic stratigraphy.

Thirty seismic refraction profiles were made in the survey area by using sonobuoys with two 400 -cc airguns as the source of sound. The shooting track lines of these profiles are the heavy line segments in Figure 4. The vertical temperature profiles at 56 different sites were measured by using a Pogo sediment temperature probe. The location of these temperature measurements is also shown in Figure 4. Two piston cores about 10 meters in length were taken in the area, one in the north and another in the south. A standard Ewing thermograd was used to measure the vertical temperature profiles to the 10-meter depth of the holes.

In the following sections, we summarize the results of the site survey cruise. Full evaluation and interpretation of the data will be presented elsewhere.

\section{Bathymetry and Sedimentary Layer}

The pelagic sediments covering the flanks of the Costa Rica Rift in the area of study are primarily biogenic, but numerous volcanic ash layers are also present (e.g. Worzel et al., 1959; Bowles et al., 1973; Ninkovich and Shackleton, 1975). As a consequence, the sediments by and large conform to (are draped over) the basement topography. The rate of sedimentation, as determined by this survey and earlier work, is about $50 \mathrm{~m} / \mathrm{m}$.y. The morphology of the seafloor depends primarily on that 


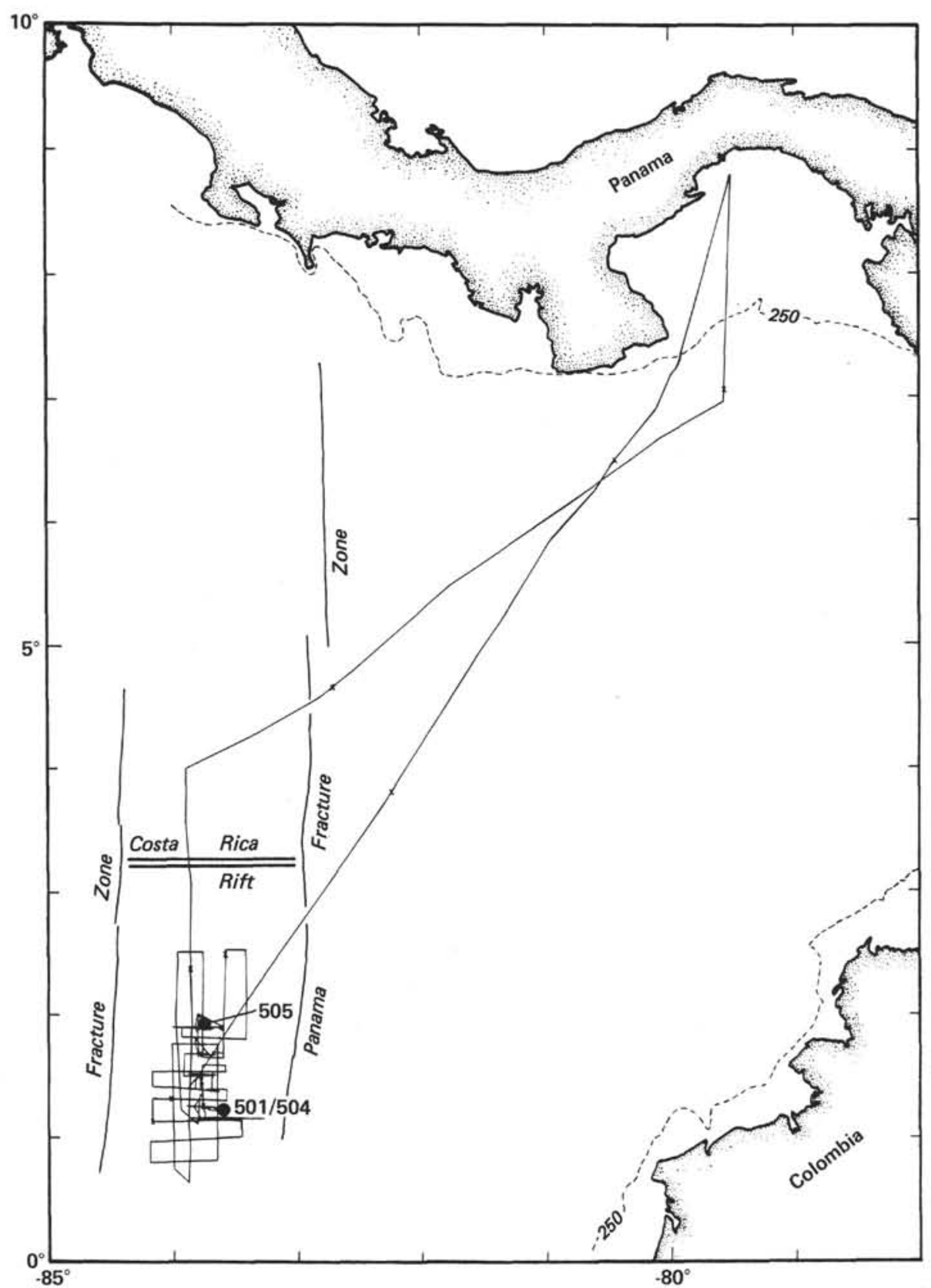

Figure 3. Location of Sites 501, 504, and 505 in the Panama Basin, showing their relationship to the Costa Rica Rift and the site survey track line grid.

of the basement; however, the basement relief is muted, and its small-scale variations are smoothed over by the sediments (Fig. 5).

In the southern part of the area, the bottom is remarkably smooth and lacking in relief compared with other ocean floors $5 \mathrm{~m}$.y. old. The sedimentary layer, which is about 250 meters thick, lies on a relatively smooth basement. Within the southern part of the survey area only one zone of exposed basement was found (at about $1^{\circ} \mathrm{N}$; see also Searle, this volume). The relief in the basement that exists appears to be associated with small escarpments, probably surface expressions of normal faults with throws less than 100 meters. The steepest slopes of the escarpments face northward, toward the ridge axis.

There is considerably more relief in the north. A ridge about $30 \mathrm{~km}$ wide and south of it a broad trough about $15 \mathrm{~km}$ wide extend east-west across the area. (The trough is centered at $1^{\circ} 50^{\prime} \mathrm{N}$.) The total change in elevation from the floor of the trough to the crest of the ridge is $\mathbf{3 0 0}$ meters. Superimposed on these major features is roughness at a scale of a few meters (see the profile in Fig. 2). This relief is due to many small slightly tilted fault blocks. The steeper slopes again face northward. The throw on the faults is 100 to 200 meters in most cases. 


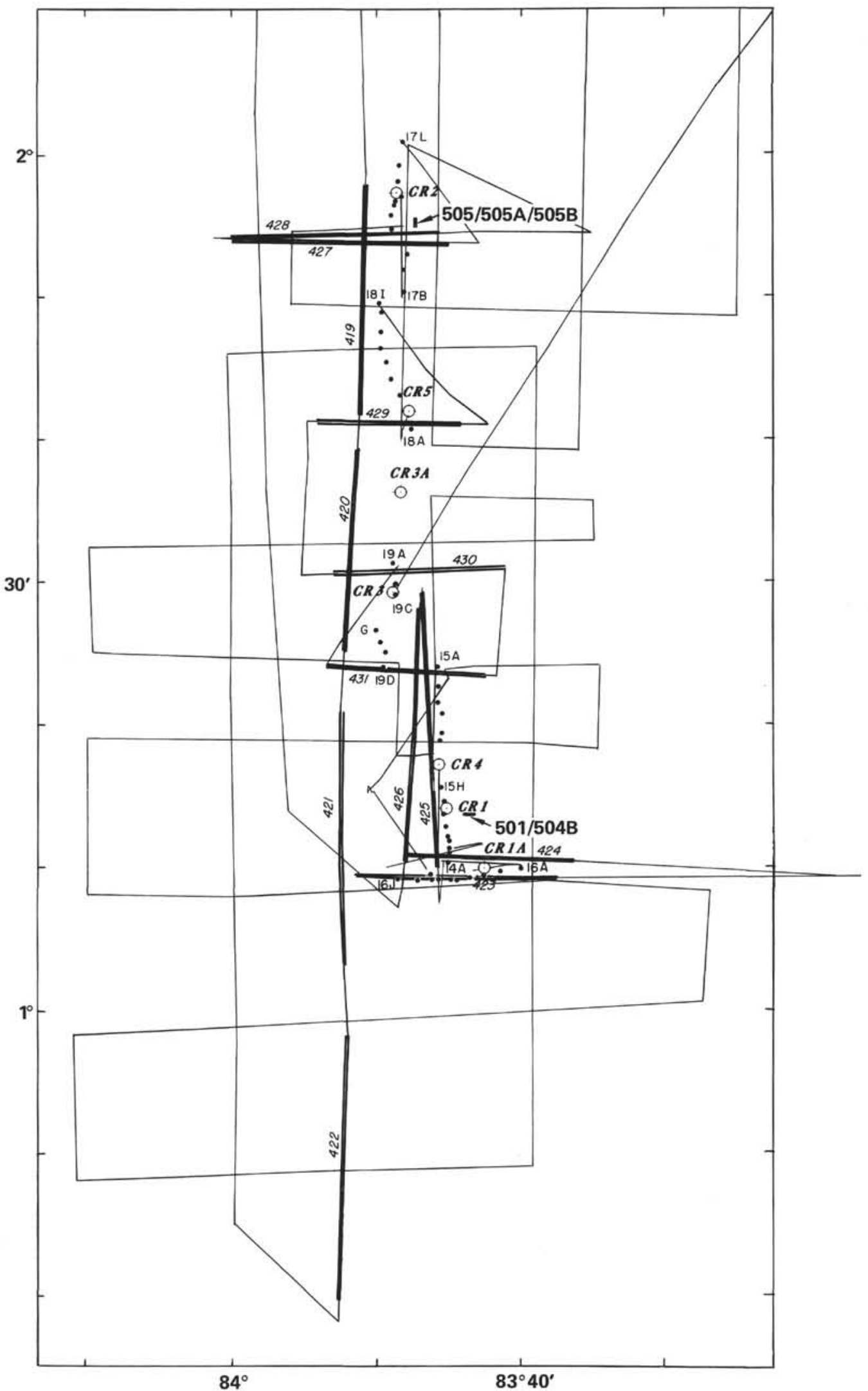

Figure 4. Detail of site survey grid, showing positions of heat flow measurements (circles, 14A-18I; compare with Fig. 2) and seismic refraction profiles (heavy lines, 419-428). Recommended drilling targets are CR 1 to CR 5. Actual drilling sites (501, 504B, 505, 505A, 505B) are also shown. 


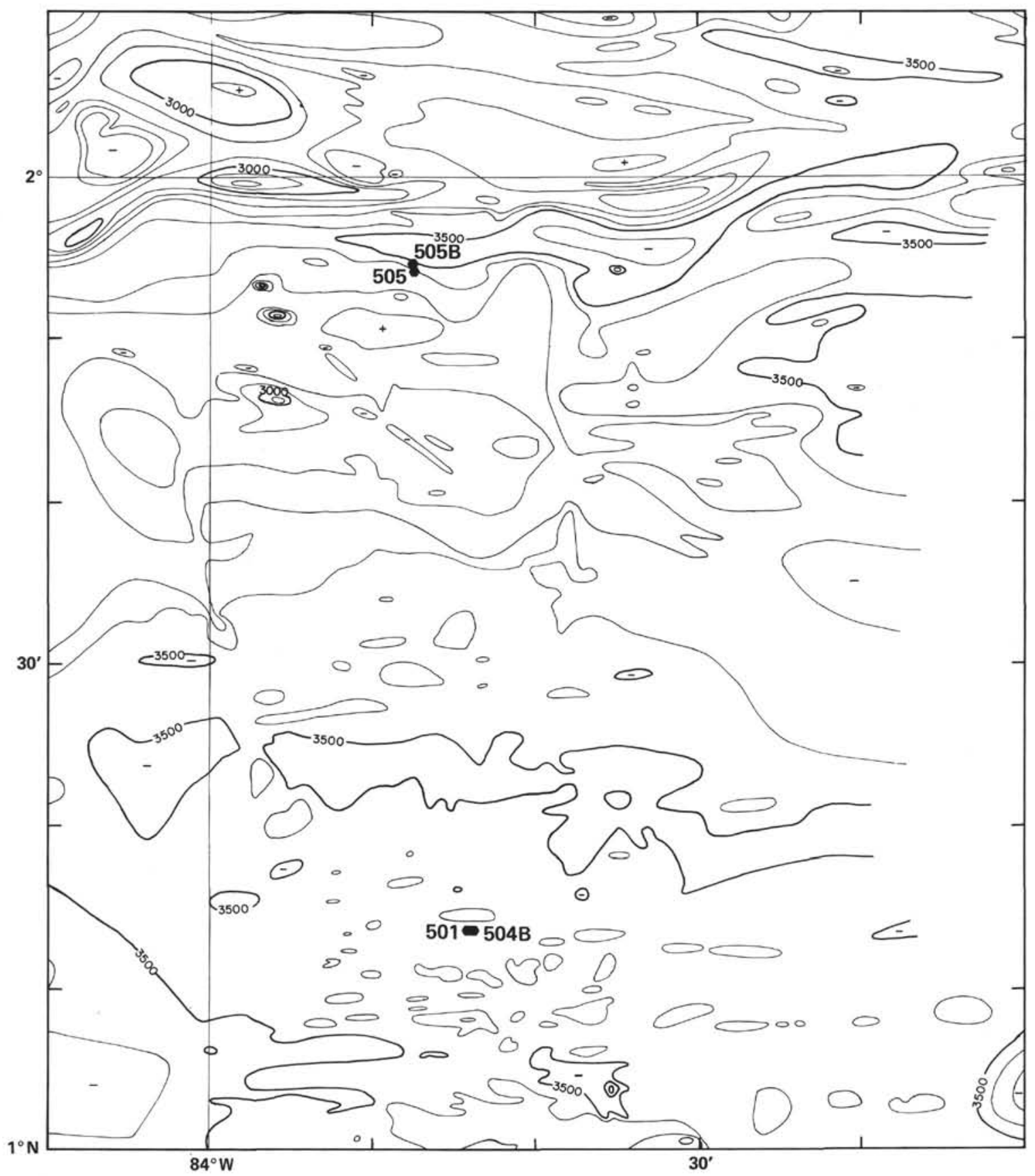

Figure 5. Bathymetry of the Costa Rica Rift site survey grid. Contour interval is $100 \mathrm{~m}$.

At a few of the larger escarpments, the basement is exposed; however, diffraction patterns from the brink and toe of the escarpments obscure basement on the seismic reflection records. The outcrops can be seen more clearly on the $3.5-\mathrm{kHz}$ echo-sounding records. The ash layers in the sediments are strong acoustic reflectors that reveal the structure of the upper 10 meters clearly. The sub-bottom reflections due to the ash layers disappear at the outcrops.

A north-south deep-tow profile was made over the northern part of the area (Klitgord et al., 1975; Fig. 6). The profile crossed the trough centered at $1^{\circ} 50^{\prime} \mathrm{N}$. The near-bottom soundings obtained show that the fault plane escarpments are steep; the basement is often exposed to the seawater. Figure 6 shows a tracing of the deep-tow profile which shows bathymetry similar to Figure 2.

The basement ridges and troughs have a strong eastwest orientation; they parallel the ridge crest and the trends of magnetic lineation. This orientation was especially obvious when the reflection profile records made on north- or south-running tracks were compared with those made on east- or west-running tracks. On the eastwest tracks, strong side reflections from the basement filled the bottom half of the record, and each echo could be traced for many kilometers. Side echoes were much 


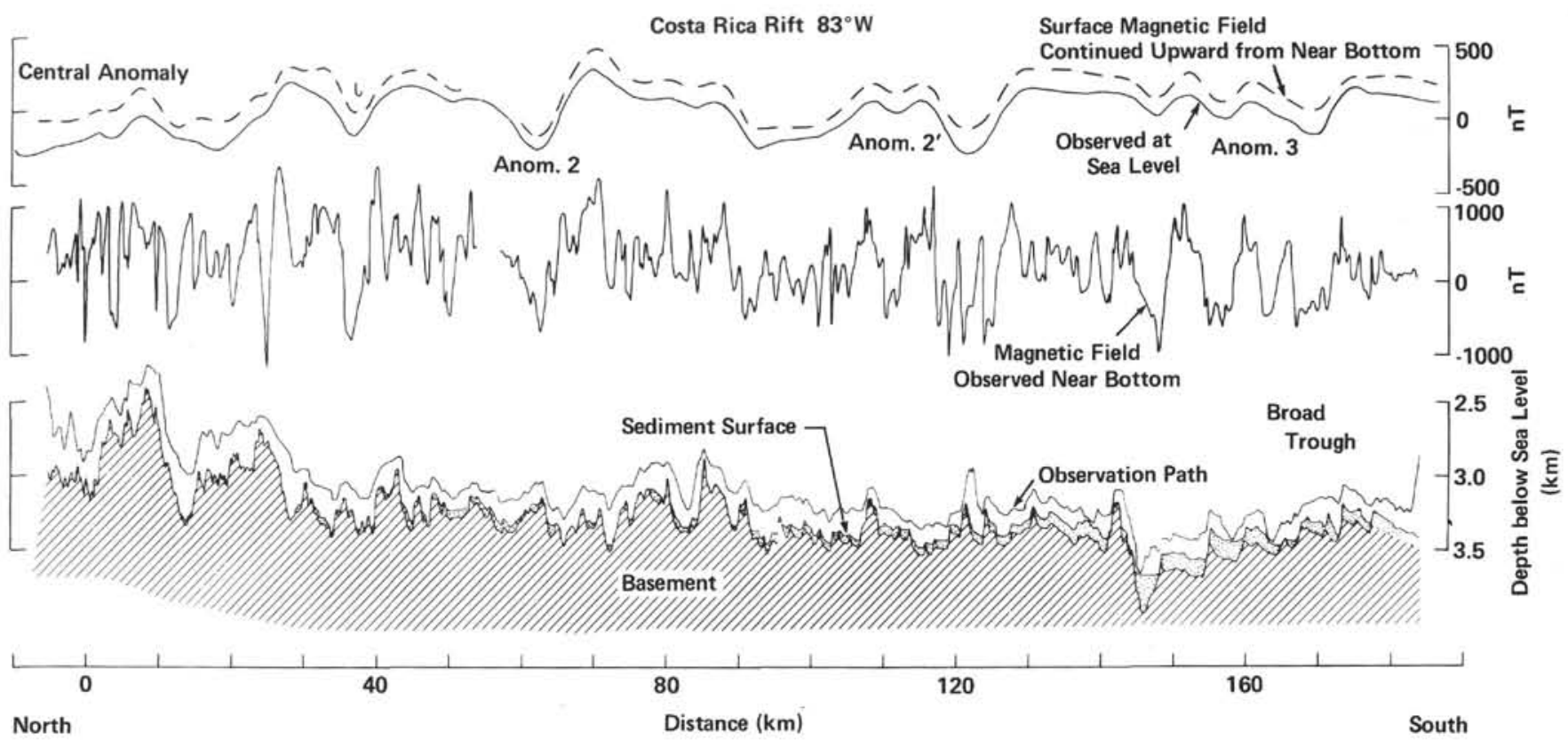

Figure 6. The near-bottom geophysical profile over the Costa Rica Rift projected along $005^{\circ}$ (based on Klitgord et al., 1975). The uppermost profile compares the magnetic field observed at sea level with that continued upward from near the bottom to the surface. The center profile gives the magnetic field observed near the bottom. The lower profile gives the depth of the deep-tow observation path, the depth of the sediment surface, and the depth of the basement.

more poorly developed in the north- and south-running tracks.

It is not clear from the seismic records whether the faulting in the basement cuts through the sediments. In the south, basement faulting seems to predate sedimentary deposition. These faults probably formed near the ridge's spreading axis and may be analogous to the faults near the axis of the Galapagos Spreading Center (at $86^{\circ} \mathrm{W}$; see Crane, 1978 and Allmendinger and Riis, 1979). In the north, however, particularly near the broad ridge and trough complex, there are strong indications that some of the fault displacements occurred after a major portion of the sedimentary blanket was deposited. Some epicenters have been located in the area, suggesting recent off-axis tectonic activity.

\section{Magnetic Anomalies}

The magnetic anomaly pattern over the Costa Rica Rift is well developed (Klitgord et al., 1975; Lonsdale and Klitgord, 1978). The map in Figure 7 shows the intensity of the residual magnetic anomalies along several north-south tracks. The anomalies related to major periods of normal and reversed field directions over the past $10 \mathrm{~m} . \mathrm{y}$. are obvious and correlate in a striking way from track to track. The alignment of the anomalies is only a few degrees from due east-west. There is no evidence of any fracture zones between the two major fracture zones that bound the Costa Rica Rift on the east and west (Fig. 1).

Magnetic anomalies 2A, 3, 3A, and 4 are below the survey area. They allow us to date the floor near Site 505 as 3.9 Ma and the floor near Sites 501 and 504 as 5.9 Ma. The half spreading rate of the Costa Rica Rift at the time when the ocean floor below the survey area was formed was $3.6 \mathrm{~cm} / \mathrm{yr}$ (Klitgord et al., 1975).

\section{Geothermal Phenomena}

Vertical sediment temperature profiles at depths to 5 meters were measured at 56 locations by using a 5 -meter lance with five outriggered thermistor probes (see Langseth and Herman, 1981). The temperature profiles were acquired in six sets (numbered 14 to 19 in Fig. 4); each set comprises 8 to 12 profiles. Five of the sets were acquired along a nearly north-south line $100 \mathrm{~km}$ long (see Figs. 2 and 4). One shorter set was acquired along a line running east-west, normal to the long north-south line and at its southern end.

Two more detailed temperature-depth profiles were made with our standard thermograd apparatus mounted on a piston corer. Deeper vertical profiles can be obtained with this equipment, about 10 meters in this case. The corer also provided samples of sediment for thermal conductivity measurements, which were made with a needle probe device. The measurements of thermal conductivity in the core taken in the southern part of the survey area had an average of $0.75 \mathrm{~W} / \mathrm{m}{ }^{\circ} \mathrm{K}$. Figure 8 shows that the values of thermal conductivity remained constant as depth increased.

In the southern part of the survey area (south of $1^{\circ} 25^{\prime} \mathrm{N}$ ), the thermal gradients observed average 0.267 $\pm 0.026^{\circ} \mathrm{C} / \mathrm{m}$ when four anomalously high measurements are ignored. In general, the gradients are extremely uniform.

Two of the measurements yielded values that are $50 \%$ higher than the average. These high values appear to be quite local features, since the two adjacent mea- 


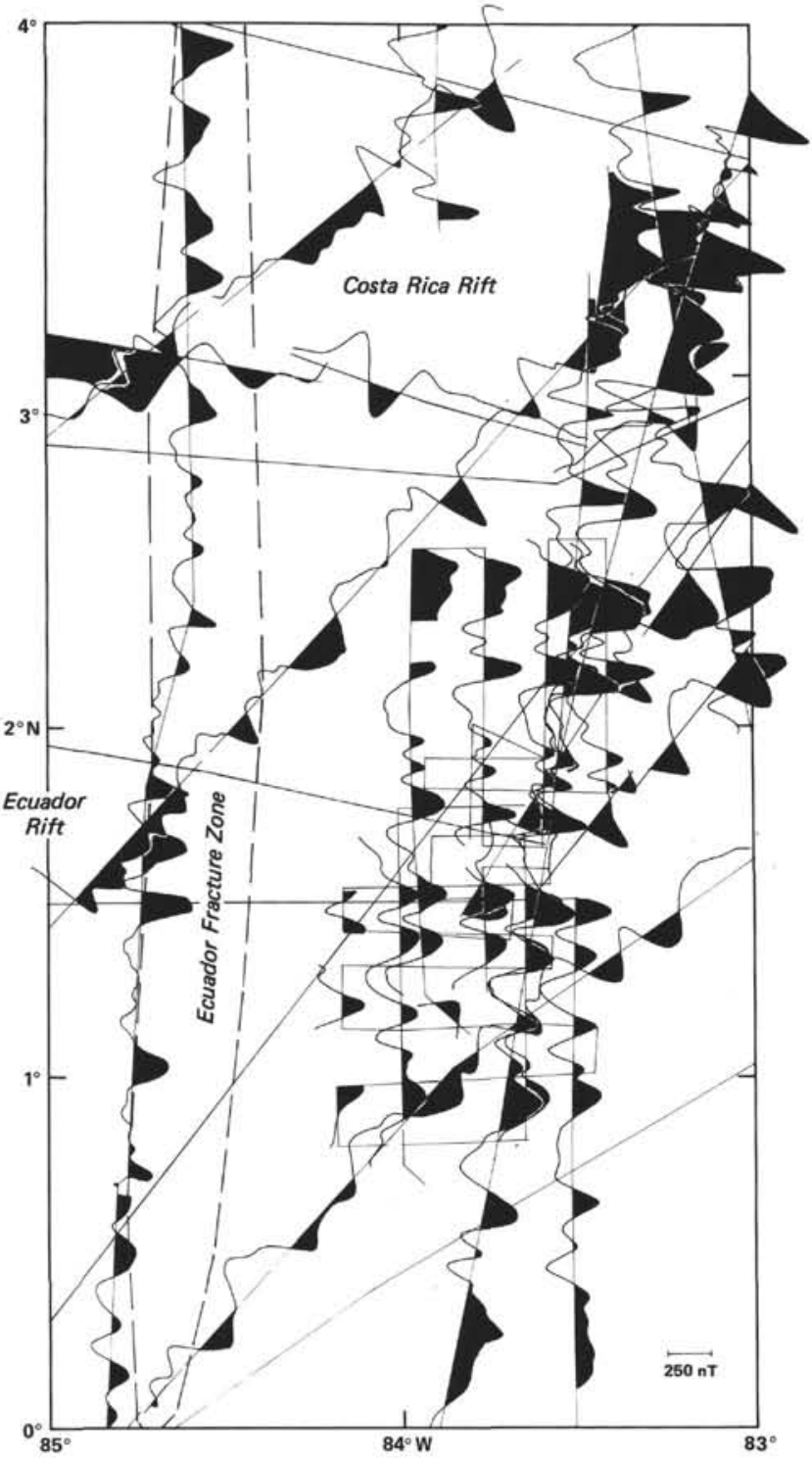

Figure 7. Magnetic anomalies observed on ships' tracks across the Costa Rica Rift and the site survey area.

surements did not yield high values. One isolated value that was $9 \%$ lower than the average was also observed in the area.

Full penetration of the 5-meter lance was achieved at each measurement point. All profiles of temperature versus depth fit a straight line within the temperature measurement error, which is a few thousandths of a degree. This indicates that the heat flow rate is uniform to a depth of 5 meters. The data give no evidence of transient heat flow phenomena or of the advection of water through the sediments. The mean value obtained here is considered to be one of the most accurate and reliable made in the seafloor.

The heat flow results along the nearly $100-\mathrm{km}$ line are shown in profile form over a nearby seismic reflection line in Figure 2. In this figure, the heat flow values are also compared with the heat flow calculated from a simple cooling half-space model of the ocean lithosphere.

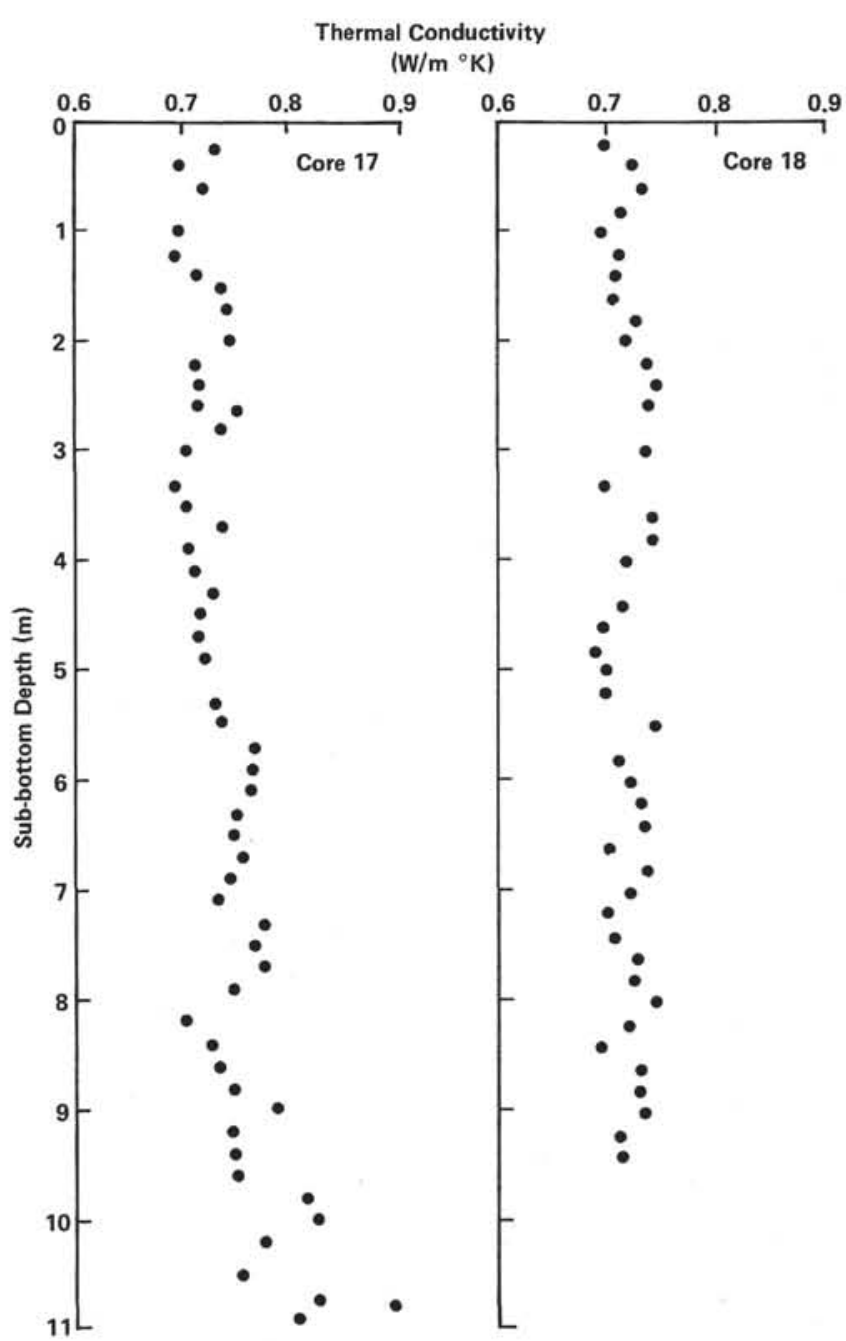

Figure 8 . Thermal conductivity $\left(\mathrm{W} / \mathrm{m}^{\circ} \mathrm{K}\right)$ versus depth in two piston cores obtained from high heat flow area during Leg 17, Cruise 21 of R/V Conrad.

The values at the southern end of the profile are uniform and in good agreement with the theoretically predicted values. At the northern end, the observed heat flow values are relatively low and much more variable. A gradient as low as $0.016^{\circ} \mathrm{C} / \mathrm{m}$ was observed at one station in the broad trough. On the average, the conductive heat flow through the sediments in the trough is only 10 to $20 \%$ of that theoretically expected. The sediments cored in this region are visually similar to those in the south, and the mean thermal conductivity is the same within the certainty of determination (see Fig. 8).

The vertical temperature profiles at each station in the northern area were linear within measurement error. Full penetration was achieved at all stations except Station $18 \mathrm{~B}$, where the probe penetrated a meter or so and then hit a hard layer (probably basement).

Taken all together, the heat flow measurements suggest a nearly linear variation between the very low heat flow area in the north and the high heat flow area in the south. The measurements thus cover a transition zone in the thermal regime of the sediments and crust. This 


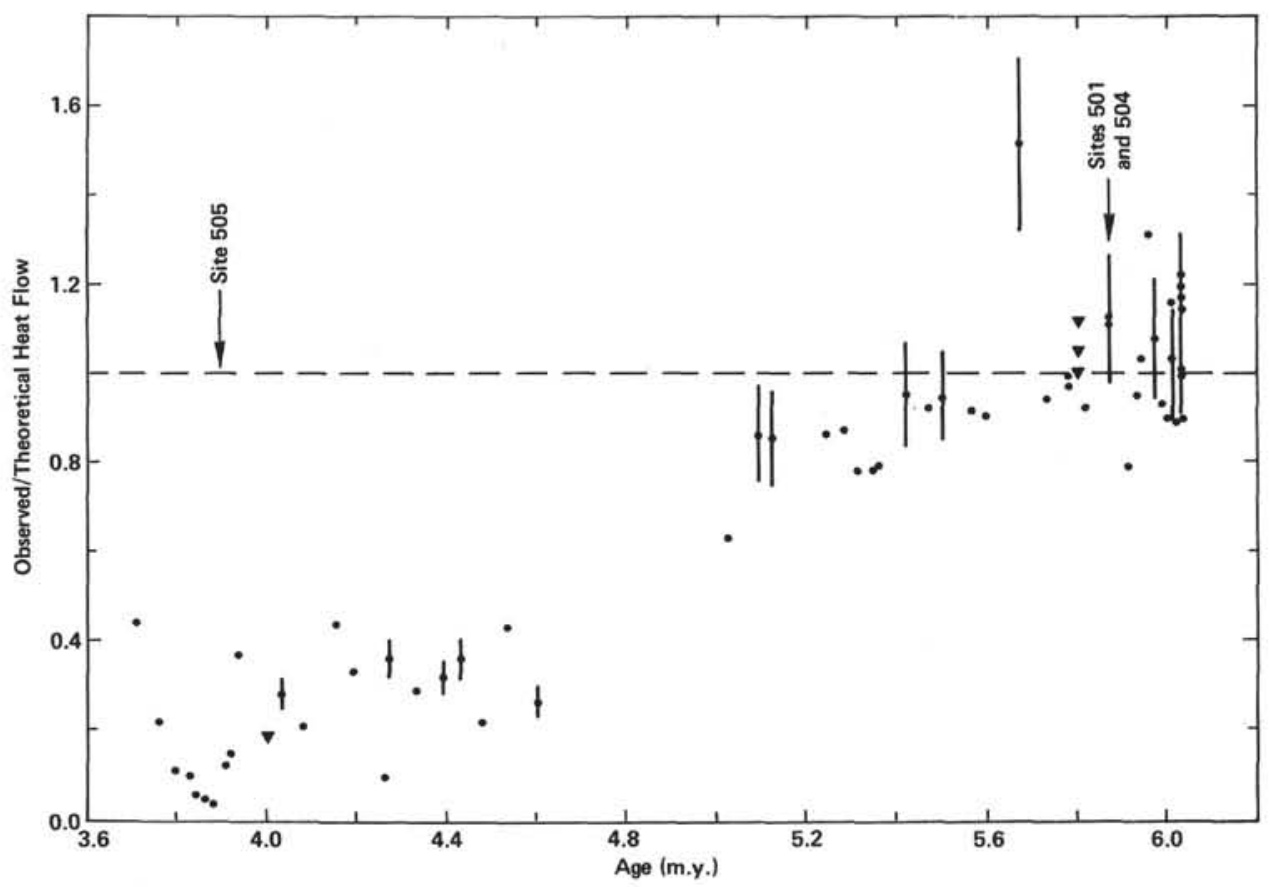

Figure 9. The ratio of observed to theoretical heat flow plotted versus crustal age. Crustal age is as determined from magnetic anomalies. The observed heat flow data are the heat flow measurements shown in Figure 2. Vertical lines are error bars.

transition zone is shown most clearly in Figure 9, where the ratio of observed to theoretical heat flow is plotted versus the age of the ocean floor.

\section{Seismic Refraction Results}

Fourteen sonobuoy seismic refraction profiles were made in the area at the locations indicated in Figure 4. Profiles were acquired running both north-south (perpendicular to the ridge axis) and east-west. Arrival time versus distance relationships were analyzed in terms of plane layers of uniform velocity. The results of these analyses are shown graphically in Figures 10 to 13 . The results can be divided into two groups: those in the southern high heat flow area, where both compressional and shear arrivals were strong at distances up to $15 \mathrm{mi}$., and those in the northern low heat flow region, where no shear arrivals were obtained and the compressional wave arrivals were significantly weaker. Much of the difference can be attributed to the greater roughness of the basement surface in the northern area; however, greater attenuation in the basement layers in the northern area may also be a factor.

The results of the refraction profiles in the southern (high heat flow) region are shown in Figures 10 to 12 . In many instances, refractors from the uppermost basement layer were observed as first arrivals. These velocities are thus presented with considerable confidence. They average $4.7 \mathrm{~km} / \mathrm{sec}$ but range widely (from 4.3 to $5.1 \mathrm{~km} / \mathrm{sec}$ ). The mean velocity in the uppermost layers is considerably higher than commonly assigned to Layer $2 \mathrm{~A}$ at 5 m.y. (see Houtz and Ewing, 1976). Layer 2A, which is a low velocity layer $(\approx 3.5 \mathrm{~km} / \mathrm{sec})$, is often observed near ridge axes and is thought to be associated

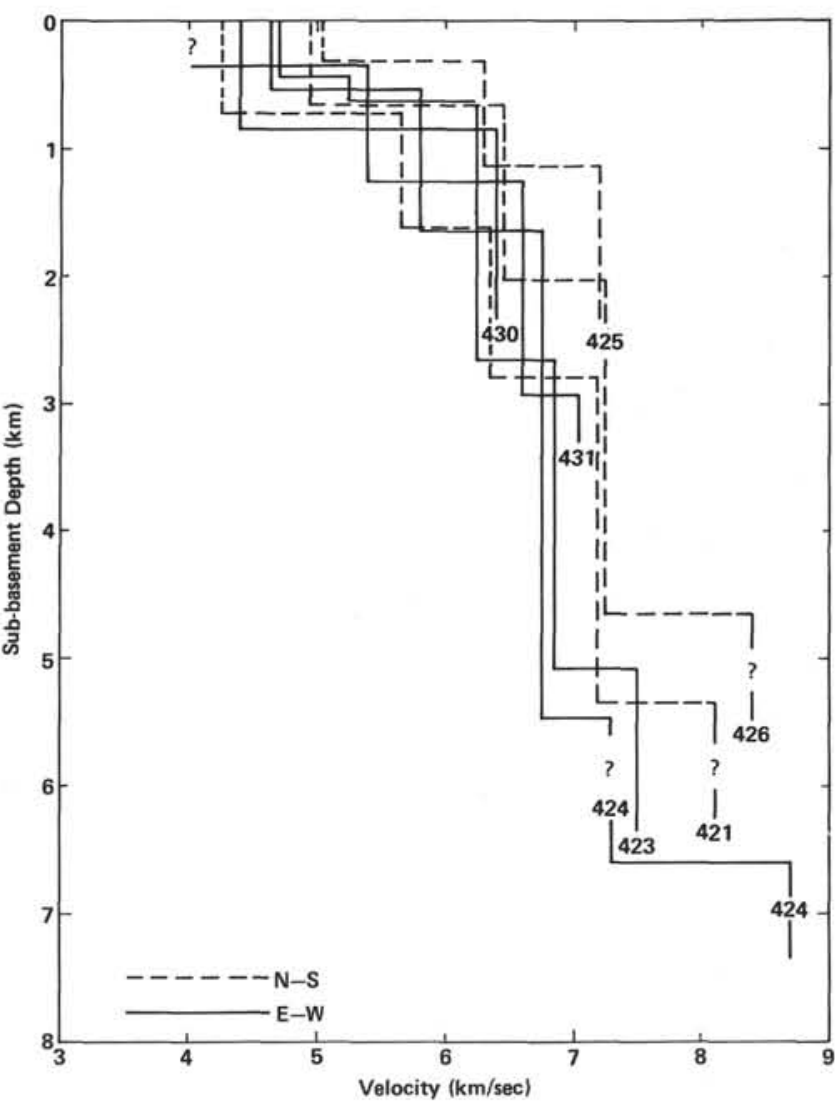

Figure 10. Compressional wave velocity structure for the high heat flow zone (Refraction Stations 421-425 and 430-431 in Fig. 4). Velocity is plotted versus sub-basement depth in $\mathrm{km}$. 
with a high degree of fracturing in the volcanic carapace. The mean velocity profile for compressional waves ( $V_{p}$ in Fig. 11) is similar to that observed in the oblique seismic experiment performed at DSDP Site 417 by Stephen et al. (1980). The fractures of the upper basement layers may be cemented in the high heat flow zone, but the variability of the layer's thickness and velocities in the upper $1.5 \mathrm{~km}$ indicate large lateral variability in layer thicknesses.

In nearly all of the profiles, the shear waves from the lower part of Layers 2 and 3 were observed. The solutions are shown in Figure 12. The variability is much reduced in comparison to the compressional wave results, as is typical in crustal refraction work. Poisson's ratios, $\delta$, were calculated by using the ratio of compressional to shear wave velocity, $V_{p} / V_{s}$. Values of 0.30 were found at depths up to $3.5 \mathrm{~km}$ (Fig. 11); the value decreases to about 0.22 below that depth. This decrease has also been reported by Christensen and Salisbury (1975), and it is believed to be associated with the presence of a gabbroic layer at the base of the crust. In general, the velocity structure observed is rather typical of ocean crust. There is no significant difference in velocity between the north-south and east-west refraction profiles.

In younger crust (Fig. 13), the mean velocity profile is about the same in the upper crust. There were two low velocities in the uppermost refractor ( 3.3 and $3.9 \mathrm{~km} /$ $\mathrm{sec}$ ). These low velocities may be associated with porous layers. In general, these profiles do not extend as deeply into the crust because of the more rapid attenuation of refracted arrivals with distance.

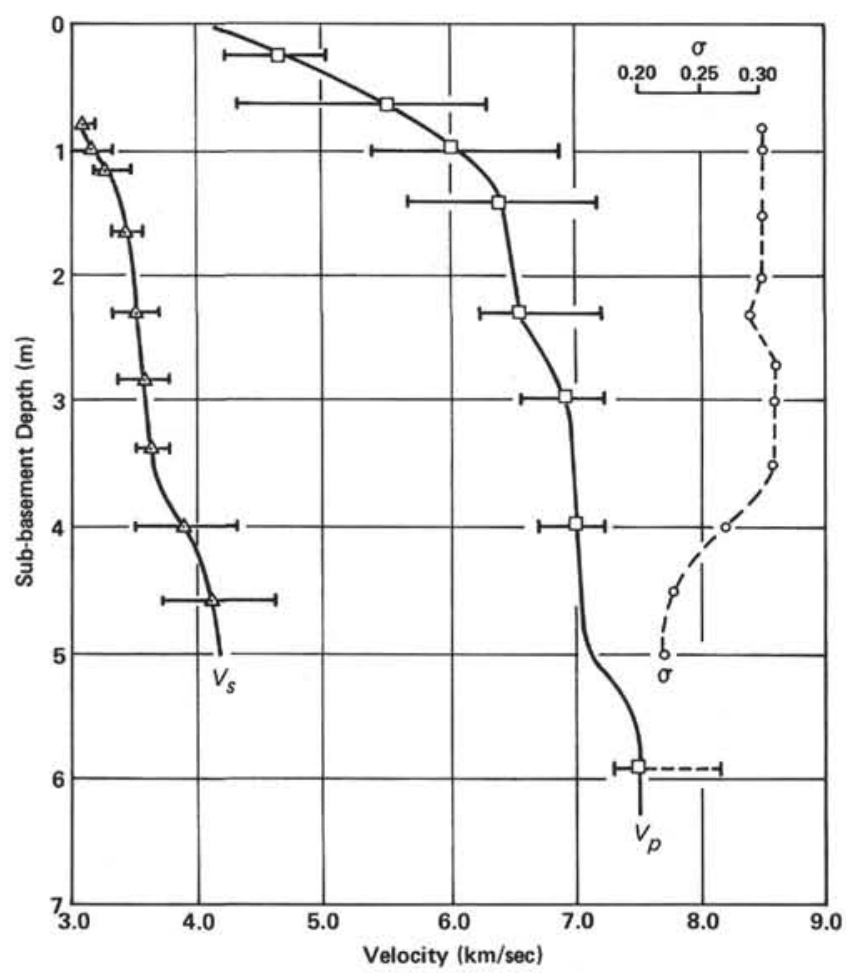

Figure 11. Mean velocity profiles for compressional $\left(V_{p}\right)$ and shear $\left(V_{s}\right)$ waves for the refraction stations listed for Figure 10. Poisson's ratio $\left(V_{p} / V_{s}\right)$ is plotted on the right side of the diagram.

\section{GEOTHERMAL MODELS}

\section{The High Heat Flow Zone}

The heat flow measurements made in the vicinity of $1^{\circ} 10^{\prime} \mathrm{N}$ show uniform values of about $200 \mathrm{~mW} / \mathrm{m}^{2}$, and

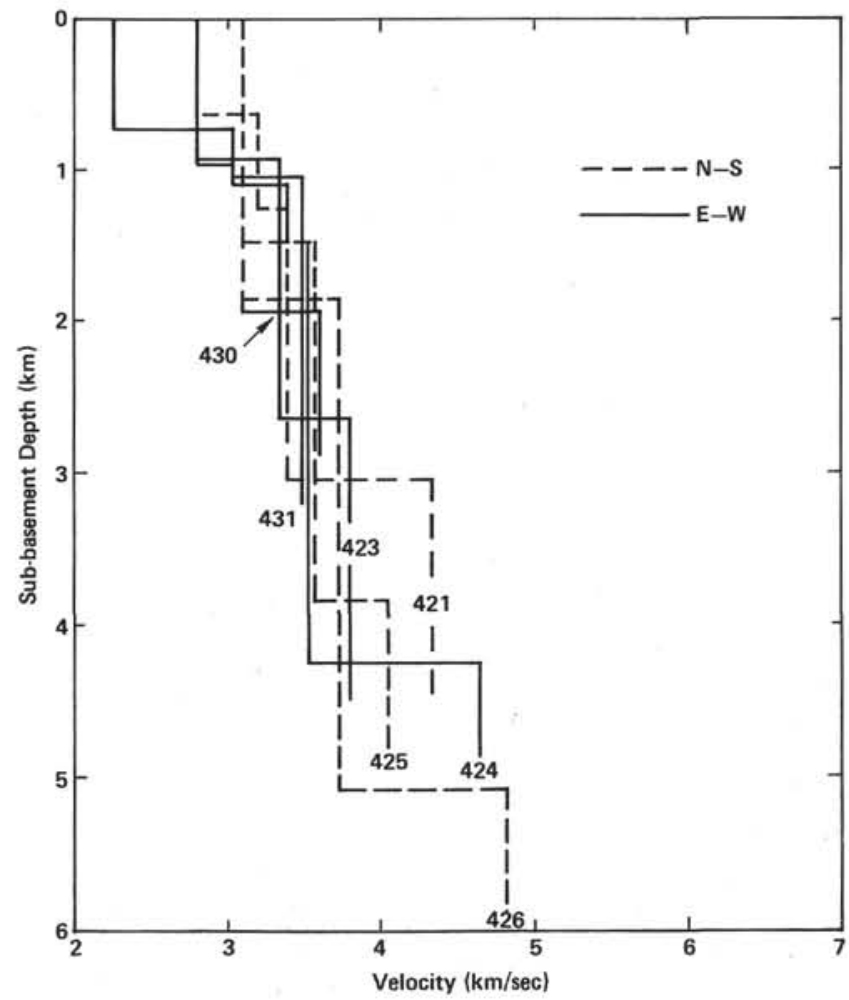

Figure 12. Shear wave velocity structure for the high heat flow zone (Refraction Stations 421 to 425 and 430 to 431 in Fig. 4).

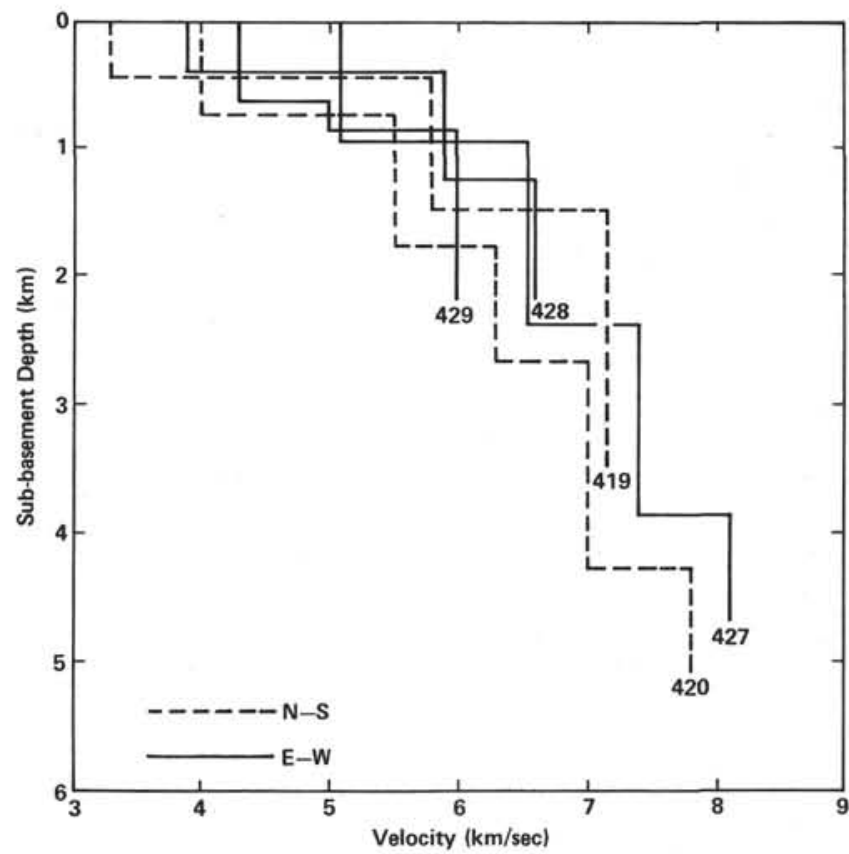

Figure 13. Compressional wave velocity structure for the low heat flow zone (Refraction Stations 419, 420, and 427 to 429 in Fig. 4). 
this value is close to that expected over 5.5 m.y. old ocean crust. It appears, therefore, that in general the sedimentary layer is in conductive thermal equilibrium with the lithosphere. The surface gradients of $25^{\circ} / 100$ $\mathrm{m}$ imply temperatures of about $65^{\circ} \mathrm{C}$ at the base of the 250-meter-thick sedimentary layer. Beneath the isolated high heat flow values, where gradients reach $36^{\circ} / 100 \mathrm{~m}$, temperatures as high as $90^{\circ} \mathrm{C}$ may be reached at the top of the basement.

The lateral uniformity of the heat flow requires the convective circulation of interstitial water, if it exists, to be very sluggish. The isolated high values and the variation at the southern end of the site survey area may reflect limited circulation, perhaps in locally more fractured zones in the crust. If heat flow is by conduction alone, the heat flow values and reasonable estimates of the crustal conductivity $\left(2 \mathrm{~W} / \mathrm{m}{ }^{\circ} \mathrm{C}\right)$ imply that the gradient in the crust will be about $10^{\circ} / 100 \mathrm{~m}$, or $100^{\circ} / \mathrm{km}$. Temperatures of 500 to $560^{\circ}$ will be attained at the base of the crust.

\section{The Low Heat Flow Zone}

The lowest values of heat flow observed in the northern end of the site survey area (near $2^{\circ} \mathrm{N}$ ) are only $10 \%$ of the predicted heat flow. The low surface gradients of 2 to $3 \% / \mathrm{km}$ indicate low temperatures in the uppermost crust, probably because of the efficient advection of heat by extensive seawater circulation in basement. Basement temperatures will depend on whether there is vertical advection of pore waters through the sediment. A simple model of dominantly lateral advection-with circulation between widely spaced basement outcrops and no flow through basement-suggests temperatures at the sediment/basement contact of only 4 to $6^{\circ} \mathrm{C}$ above bottom water temperature. A model that assumes vertical advection-by recharge of bottom water through the sediments into basement-predicts basement temperatures of 15 to $20^{\circ} \mathrm{C}$. The real situation is probably considerably more complex; nevertheless, the very low surface heat flows require low basement temperatures of about 5 to $20^{\circ} \mathrm{C}$. Temperature measurements at Hole 505 indicate no vertical advection, since a basement/ sediment interface temperature only $6^{\circ}$ above bottom water temperature was observed.

\section{The Transition Zone}

The 100-km survey of heat flow measurements, a distance that corresponds to about $1.6 \mathrm{~m} . \mathrm{y}$. in terms of crustal age, shows a gradual transition from younger crust in which intercrustal seawater circulation is vigorous to older crust in which the circulation is capped and perhaps stopped. A question that arises is whether the spatial variation from north to south mimics temporal variations in the thermal regime. That is, did seawater circulation also dominate heat transfer in the crust in the southern region (at $1^{\circ} \mathrm{N}$ ) $2 \mathrm{~m}$.y. ago? If so, the temperatures in the upper crust would have been 40 to $50^{\circ}$ cooler than they are now. Over the past 2 m.y., the crust would have been heated as the convective flow of heat gave way to conductive flow. If the progressive change in the heat flow measurements reflects the history of heat transfer in the crust, the gradual variations observed from north to south define time constants of the sealing process.

Alternatively, the transition zone may result from the changes that occur in the geological structure of the seafloor as one proceeds from north to south. Studies of heat flow variations in the world's ocean ridge system indicate that the most important factor in the degree of convective pore water movement is the completeness of the sedimentary blanket and its hydraulic resistance. There is evidence that if basement exposures are spaced less than $30 \mathrm{~km}$ apart, open seawater circulation will depress the crustal temperatures. The area of exposed crustal rock need be only a small percentage of the total area.

The seismic reflection profile in Figure 2 clearly shows that the basement at the southern end of the profile is significantly smoother than in the region of low heat flow. Thus, it is likely that a substantially thinner sedimentary layer would have been sufficient to cover the basement completely. Thus, water circulation in the crust where high heat flow is now observed may have been stopped more than 2 m.y. ago.

For the same reasons, the rougher basement topography in the low heat flow zone may require much more than $2 \mathrm{~m}$.y. at present sedimentation rates to cover the exposed basement surfaces in the area. Thus, the crust may remain relatively cool, as it is now, far into the future.

\section{DRILLING RECOMMENDATIONS}

As a result of the site survey cruise, two drilling targets were selected for detailed investigation (CR 1 and CR 2 in Fig. 4). The top priority target was in the southern region of uniformly high heat flow, where there was a conductive thermal gradient. This target became Sites 501 and 504. The second target was in the region of low heat flow, in the younger crust to the north, where a convective geothermal regime still exists. This target became Site 505 . Site 505 was drilled during the construction of a second reentry cone at Site 504 after the first reentry hole there was lost.

\section{ORGANIZATION OF VOLUME 69}

The eight parts of Volume 69 deal with different aspects of the drilling or geophysical experiments. They are as follows: Part I-introduction and site chapters; Part II-geophysical studies; Part III-sedimentology and paleontology; Part IV-pore-fluid and formation fluid geochemistry; Part V-basalt alteration; Part VIphysical and magnetic properties of sediments and basalts; and Part VII-igneous petrology.

A preliminary synthesis of the drilling is presented in CRRUST (1982). Owing to the complexity and great diversity of studies related to the drilling, the great number of investigators involved, and the continuation of drilling in Hole 504B during Leg 83, which supersedes some of our results, we have not prepared a synthesis for this volume. 


\section{SITE REPORT ORGANIZATION AND AUTHORSHIP}

Sites 501 and 504 are for all practical purposes a single site, and they are treated as such in the site chapter. The 31 members of the three scientific parties involved in the drilling of the holes at these sites are the authors of this report. Only the scientific participants in Leg 69 wrote the chapter for Site 505 , which is treated separately. The background and objectives of the drilling are presented in this introduction, so the site chapters begin with descriptions of the drilling operations. The site chapters give only the information necessary to account for the cruise activities at each site. Most of the downhole experiments, for example, are described and discussed in separate chapters later in the volume. Since the results of these experiments are interpreted in these other papers, the site chapters do not contain summary or conclusions sections.

The authorship of particular paragraphs and sections of the site chapters is as follows, with the leg affiliation of each participant indicated in parentheses.

Operations-Cann $(68,69)$, Langseth (69), and Von Herzen (70)

Sediment lithology-White $(68)$, Beiersdorf $(69)$, and Natland $(68,69)$ Biostratigraphy-Sancetta (69)

Igneous lithology, petrography, and chemistry-Pertsev $(68,69)$, Natland $(68,69)$, Adamson (69), Noack (69), Hubberten (70), Schrader (70), Honnorez (70), Barrett (70), and LaVerne (70)

Isotope geochemistry-Barrett (70)

Basement structure-Natland $(68,69)$

Pore- and formation-fluid geochemistry-Lawrence (68), Mottl (69), and Bender (70)

Sediment and basalt physical properties-White (68), Wilkens (69), and Karato (70)

Paleomagnetism-Furuta (69) and Levi (70)

Heat flow and temperature measurements-Langseth (69), Becker (70), and Von Herzen (70)

Logging and other downhole measurements-Zoback (68), Anderson $(68,69)$, Ponomarev $(68)$, Nekhoroshkov $(68,69)$, Cann $(68,69)$, Langseth (69), Becker (70), and Von Herzen (70)

Oblique seismic experiment-Stephen (70)

Leg 70 sedimentologists and paleontologists were of assistance during the basalt coring of the lower part of Hole 504B but did not formally participate in the writing of the site chapters for this volume.

\section{APPENDIX \\ Explanatory Notes}

\section{General Information}

The site chapters present descriptions and photographs of materials cored at Sites 501, 504, and 505. Investigators who want to obtain samples should refer to the DSDP-IPOD Sample Distribution Policy, which is stated at the front of the volume. Sample request forms may be obtained from:

\section{The Curator}

Deep Sea Drilling Project, A-031

University of California, San Diego

La Jolla, California 92093

Requests must be as specific as possible: include leg, site, core, section, interval within a section, and volume (in cubic centimeters) of sample required.

The purpose of these notes is twofold. First, they are intended to aid interested investigators in understanding (1) the terminology, labeling, and numbering conventions used by the Deep Sea Drilling Project and (2) the sediment classification and biostratigraphic framework used on Legs 68 (Site 501), 69, and 70 (Hole 504B). Second, they are intended to explain the preliminary lithologic and paleontologic data on the core forms.

\section{Numbering of Sites, Holes, Cores, and Samples}

DSDP drill sites are numbered consecutively from the first site drilled by Glomar Challenger in 1968. Site numbers differ from hole numbers in that a site number refers to a locale where one or more holes were drilled while the ship was positioned over one acoustic beacon. These holes could be located within a radius as great as 900 meters from the beacon. Several holes may be drilled at a single site by pulling the drill pipe above the seafloor (out of the hole), moving the ship 100 meters or more from the previous hole, and then beginning to drill another hole.

The first (or only) hole drilled at a site takes the site number. A letter suffix is applied to each additional hole at the same site. For example, the first hole takes only the site number, the second takes the site number with suffix $\mathrm{A}$, the third takes the site number with suffix $\mathrm{B}$, and so forth. It is important, for sample labeling purposes, to identify the hole drilled at the site, since sediments or rocks recovered from different holes usually do not come from equivalent positions in the stratigraphic column.

The cored interval is measured in meters below the seafloor. The depth interval for an individual core is the depth below seafloor at which the coring operation began to the depth at which the coring operation ended. Most core intervals are 9.5 meters long, the nominal length of a core barrel; however, the coring interval may be shorter or slightly longer. "Cored intervals" are not necessarily adjacent to each other, but may be separated by "drilled intervals." In soft sediment, the drill string can be "washed ahead" with the core barrel in place, but not recovering sediment, by pumping water down the pipe at high pressure to wash the sediment out of the way of the bit and up the space between the drill pipe and the wall of the hole. However, some material does occasionally get caught in the core barrel while the drill string is being washed ahead; thus, it is possible to have a cored interval greater than 9.5 meters.

Full recovery for a single core is normally 9.28 meters of sediment or rock, which is in a plastic liner (6.6 cm I.D.), plus a sample about 0.2 meter long (without a plastic liner) in the core catcher. The core catcher is a device at the bottom of the core barrel that prevents the cored sample from sliding out when the barrel is being retrieved from the hole. The core is then cut into 1.5-meter-long sections and numbered serially from the top of the core (Fig. 14). When a core is fully recovered the sections are numbered from 1 to 7 , with the last section shorter than 1.5 meters. The core-catcher sample is placed below the last section when the core is described, and labeled core catcher (CC); it is treated as a separate section.

When recovery is partial, the original stratigraphic position of the material in the cored interval is unknown. If the recovered material is contiguous we assign the top of this material to the top of the cored interval and number sections serially from the top, beginning with Section 1 (Fig. 14). (This technique differs from the labeling system used for Legs 1 through 45 , in which one section was numbered 0 and none was numbered 7.). There are as many sections as needed to accommodate the length of the recovered material. For example, 4 meters of material are divided into three sections, two upper sections each 1.5 meters long and a final lower section only 1.0 meter in length. If the material recovered is not contiguous, as determined by the shipboard scientists, the sections are divided and numbered serially as with contiguous material, and the gaps are labeled as voids for sediments (Fig. 14) or marked by spacers for igneous rocks (see Igneous Rocks section).

Samples are designated by the interval, in centimeters, from the top of the section to the top and bottom of the sample. A full identification number for a sample consists of leg, site, hole, core, and inter$\mathrm{val}$ (in centimeters from the top of the section). For example, a sample identification number of 69-504B-3-1, 12-14 cm is interpreted as the sample 12-14 cm from the top of Section 1 of Core 3 from the third hole drilled at Site 504 during Leg 69. A sample from the core catcher of this core is designated as 69-504B-3,CC.

\section{Handling of Cores}

A core is normally cut into 1.5-meter sections, sealed, and labeled. It is then taken to the core laboratory for processing. During these legs, long core spinner magnetism measurements, gas analyses, ther- 

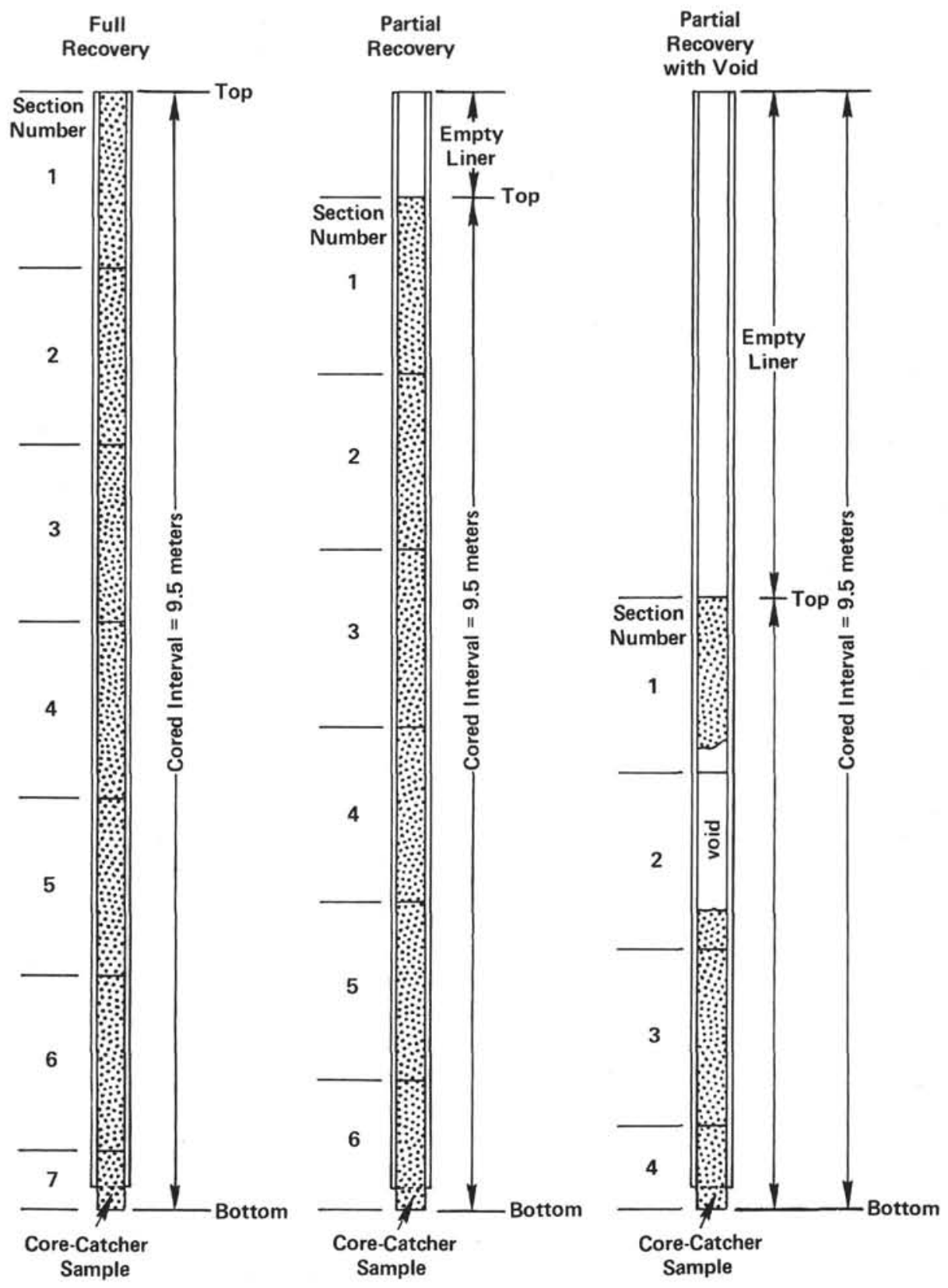

Figure 14. Procedure used to label fully and partially recovered cores.

mal conductivity measurements, and continuous wet-bulk density determinations using the gamma ray attenuation porosity evaluation (GRAPE) were made before the sections were split.

The cores were then split longitudinally into "working" and "archive" halves. Samples were taken from the "working" half for analysis. Samples were analyzed for grain-size distribution, mineralogy (by X-ray diffraction), sonic velocity (by the Hamilton frame method), wet-bulk density (by a static GRAPE technique), water content (by gravimetric analysis), carbon-carbonate content, calcium carbonate content (by the Karbonat Bombe technique), geochemistry, and paleontology, among other things.

Smear slides (thin sections) were prepared for lithified sedimentary and igneous rocks from each major lithology and most minor lithologies and examined microscopically. The archive half was then described and photographed. Physical disturbance by the drill bit and the color, texture, structure, and composition of the various lithologies were noted on standard core description forms. All prime data were microfilmed, and some were digitized for computer retrieval.
After the cores were sampled and described, they were kept in cold storage aboard the Glomar Challenger until they could be transferred to the DSDP repository. Core sections of sediments intended for the study of organic geochemistry were frozen immediately on board ship and kept frozen. All fresh and frozen cores described here are presently stored at the DSDP West Coast Repository (Scripps Institution of Oceanography).

\section{Hydraulic Piston Corer}

On Leg 69 the hydraulic piston corer (HPC) was used successfully to recover undisturbed sediments at Site 504. The high rate of recovery (average: $93 \%$ ) was attributed to the low shear strength of the sediments and calm seas. HPC-drilled holes are not given any special designation.

The principles of operation of the hydraulic piston corer are outlined in Figure 15. The hydraulic piston corer is located within the lowermost part of the drill string, and it is flush with the base of the drill bit before it is fired. Once fired, the cores ideally penetrate 4.4 
HPC is seated. Seawater is pumpe at $350 \mathrm{gpm}$ to actuate.

Locking p

pressure on

e. Fluid above

stationary piston is vented.

Core tube speed is approx.

10-20 feet per second.

At the end of the stroke

dampening ports are un

that vent the pressure fluid

and decelerate the core barrel.

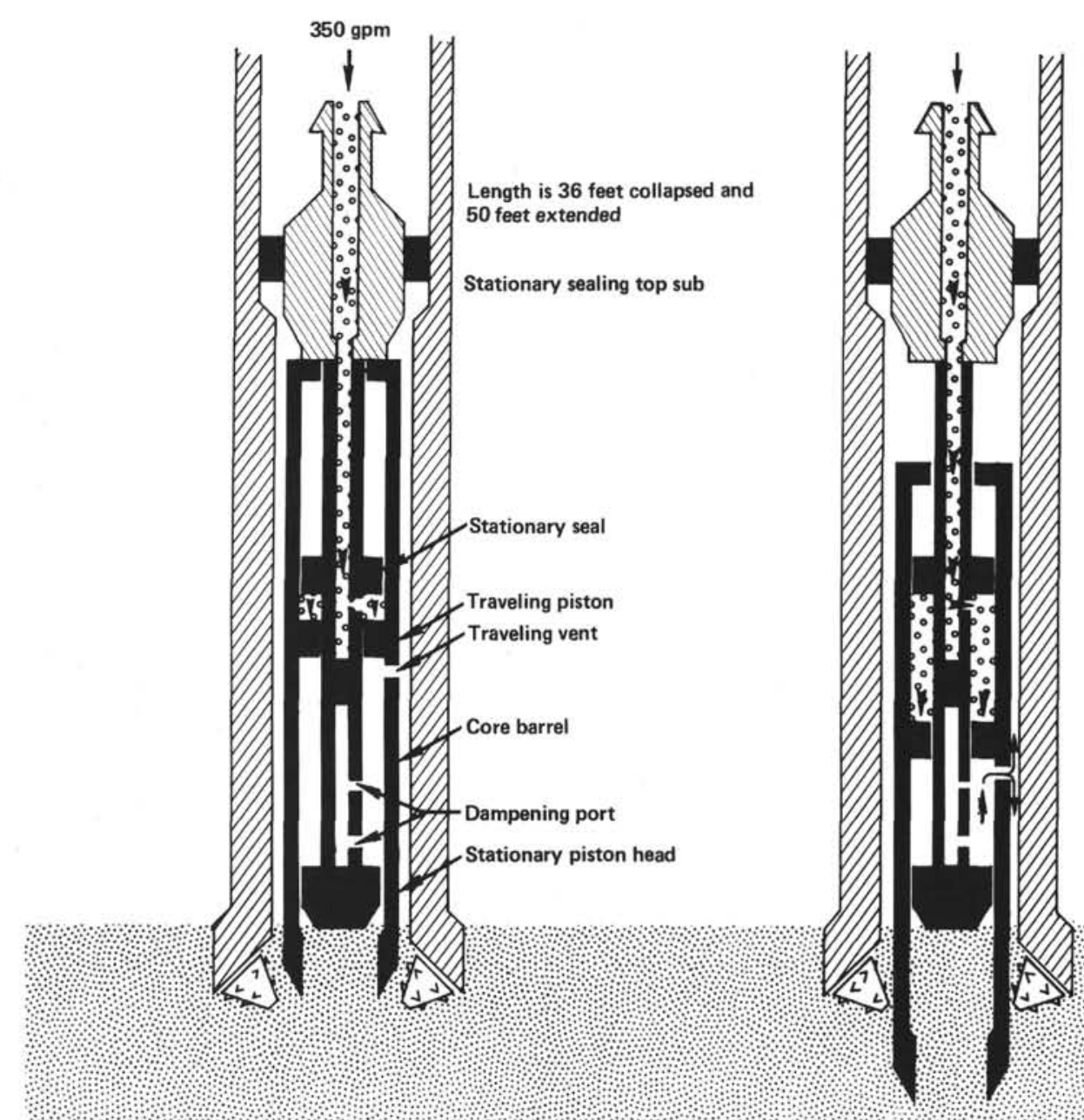

Stroke is $15^{\prime}$

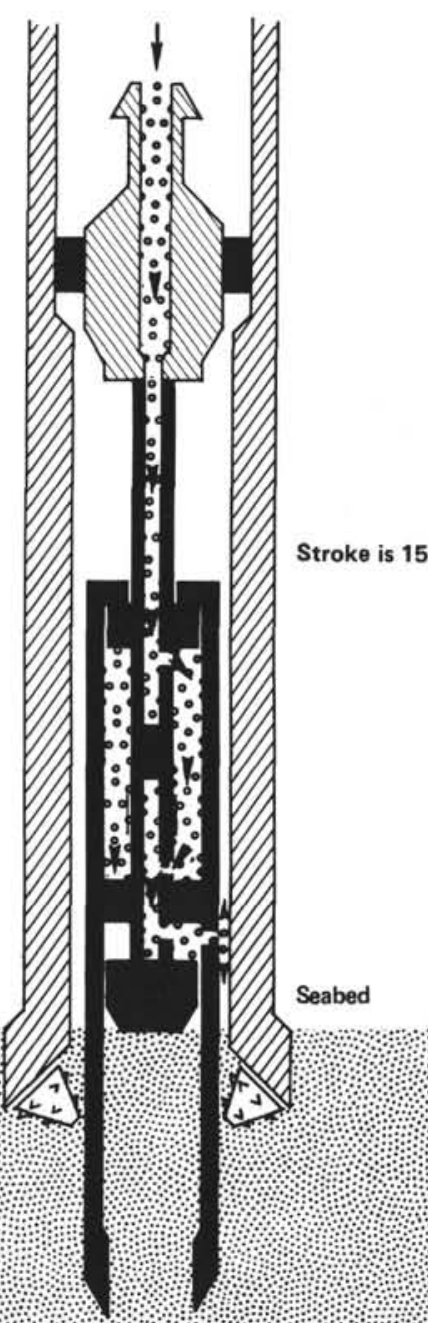


meters into the underlying sediment. The full extension of the HPC to this length is reflected on the rig floor by complete pressure bleed-off following the shot. After penetrating the sediment the HPC is pulled up 4.4 meters to a position within the lowermost part of the drill string. The whole drill string is then raised to a point where a drill string tool joint appears at the level of the rig floor. The raised interval ranges from 0 to 9.5 meters (the length of one joint of drill pipe). Thus, the total depth of the open hole beneath the drill bit can be as high as $9.5+4.4$ meters, or 13.9 meters. The drill string is then separated at the tool joint, and the inner core barrel with the 4.4 meters of sediment is pulled to the rig floor on the sandline.

After the core is removed, the inner core barrel of the HPC is reloaded and returned to the base of the drill string. The HPC drill bit then washes down through the sediment interval just previously cored, but only for a distance of approximately 3.4 meters. The last meter of lowering is done without washing. The base of the drill string is now at the desired level for the next HPC shot.

The presence of an open hole below the drill string while the HPC inner core barrel is being retrieved and reloaded and the fact that the drill string washes down 3.4 meters and is pushed the last meter begins to explain why the upper parts of many hydraulic piston cores are contaminated with material previously cored and disturbed. The raising of the entire drill string as much as $\mathbf{9 . 5}$ meters also explains why a mudline core may be taken twice.

\section{Sediments and Sedimentary Rocks}

\section{Core Description Forms}

\section{Disturbance}

Recovered rocks, particularly the soft sediments, may be extremely disturbed as a result of rotary coring, which uses a large $(25-\mathrm{cm}$ diameter) bit with a small (6.0-cm-diameter) opening for the core sample. The following disturbance categories are used for soft and firm sediment:

Slightly deformed: bedding contacts are slightly bent.

Moderately deformed: bedding contacts have undergone extreme bowing. Firm sediment is fractured.

Very deformed: bedding is completely disturbed or homogenized by drilling and sometimes shows symmetrical diapir-like structure. Firm zones may have relic "drill biscuits" in a breccia or homogeneous matrix.

Soupy: water-saturated intervals that have lost all aspects of original bedding.

These categories are indicated on the core description form in the column headed "Drilling Disturbance" (Fig. 16).

\section{Sedimentary Structures}

In the softer sedimentary cores, and even in some harder ones, it may be extremely difficult to distinguish between natural structures and structures created by the coring process. Thus, the description of sedimentary structures is optional. Locations and types of these structures appear as graphic symbols in the column headed "Sedimentary Structures" on the standard core description form (Fig. 16) and the expanded hydraulic piston core description form (Fig. 17). Figure 18 gives the key to these symbols. The key for the graphic lithology column is given in Figure 19.

Bioturbation, where detected, is noted in the graphic lithology column. A summary of the biogenic sedimentary structures (ichnofossils) most common in DSDP cores is given in Figure 20.

Color

The colors of the geologic material are determined with a Munsell or Geological Society of America rock-color chart. Colors were determined immediately after the cores were split, while they were wet.

\section{Lithology}

The lithology of the cored material is indicated in graphic lithology column of the core description form. The lithology is represented by a one or more patterns. The patterns correspond to the end members of sediment constituents, such as clay or nannofossil ooze. Patterns for terrigenous constituents appear on the right side of the column; patterns for biogenic constituents appear on the left side of the column. The abundance of any component is indicated approximately by the proportion of the graphic column its pattern occupies. For example, the left $20 \%$ of the column may have a diatom ooze pattern and the right $80 \%$ of the column may have a silty-clay pattern, indicating sediment composed of $20 \%$ diatoms and $80 \%$ mud.

Because of the difference in the length-to-width ratio between the actual sediment core and the graphic lithology column, it is not possible to reproduce structures as they appeared in the core; they become highly flattened and distorted. The same is true for rock fragments or pebbles in the cores. As a result, the locations of pebbles are shown by a solid square, and the depth of small patches of ash or other lithologic changes are indicated by a triangular inset of the appropriate lithologic symbol on the right side of the lithologic column (Fig. 19). This convention is used only for lithologies that do not extend across the entire core.

The content, format, and terminology used in the written description of the core on the core description forms (Figs. 16 and 17) are not controlled beyond the name assigned to the lithology, which is derived from the lithologic classification (described below). Colors and such additional information as structures and texture appear in the text portion of the core description.

Smear slide (or thin section) compositions, carbonate content (\% $\mathrm{CaCO}_{3}$ ), and organic carbon content determined on board ship are listed below the core description on these forms. Two numbers separated by a hyphen refer to the section and centimeter interval, respectively, of the sample. The locations of these samples in the core and a key to the codes used to identify these samples are given in the column headed "Samples" (Figs. 16 and 17). The locations and intervals of organic geochemistry (OG) and intersititial water (IW) samples are given in the lithology column.

\section{Lithologic Classification of Sediments}

The classification system used here was devised by the JOIDES Panel on Sedimentary Petrology and Physical Properties (SPPP) and adopted for use by the JOIDES Planning Committee in March 1974. The classification is descriptive rather than genetic, and divisions between different types of sediment are somewhat arbitrary. A brief outline of the conventions and descriptive data used to construct this classification follows. Since the range of sediment types recovered is limited, we do not present the entire classification scheme but only what is pertinent to our cores. This excludes terrigenous, most volcanogenic, and special (e.g., hydrothermal) sediment types. The most recent publication of the complete sediment classification system was published in Ross, Neprochnov, et al. (1978).

\section{Conventions and Descriptive Data}

Composition and texture. In this classification system composition and texture are the only criteria used to define the type of sediment or sedimentary rock. Composition is most important for describing sediments deposited in the open ocean, and texture becomes significant for hemipelagic and nearshore sediments. These data come principally from visual estimates of smear slides using a petrographic microscope. The estimates are based on the areal abundance and size of the components on the slide and may differ somewhat from more accurate analyses of grain size, carbonate content, and mineralogy (see Special Studies). Because of past experience, the quantitative estimates of distinctive minor components are accurate within $2 \%$, but for major constituents the accuracy is poorer $( \pm 10 \%)$. All smear slide estimates were done on board. Carbonate content is difficult to estimate from smear slides. Therefore, for many cores we determined the percentage of carbonate by using the "Karbonat Bombe" technique of Müller and Gastner (1971). This method involves treating a powdered sample with $\mathrm{HCl}$ in a closed cylinder. The resulting pressure of $\mathrm{CO}_{2}$ is proportional to the carbonate $\left(\mathrm{CaCO}_{3}\right)$ content of the sample, and this value is converted to percent $\mathrm{CaCO}_{3}$ by using the calibration factor of the manometer. The accuracy of this method is $\pm 5 \%$. Carbonate content determined in this manner is listed on the core description forms below the lithologic description.

The textures of the sediments and the percentages of sand, silt, and clay estimated from the smear slides include all constituents. Thus, a diatomaceous ooze will have a greater percentage of silt-sized particles than a nannofossil ooze because of the different size of the tests of the two planktonic groups. This convention causes some confusion when terrigenous sediments that contain a significant number of microfossils are named. For example, a diatomaceous silty clay may have less 


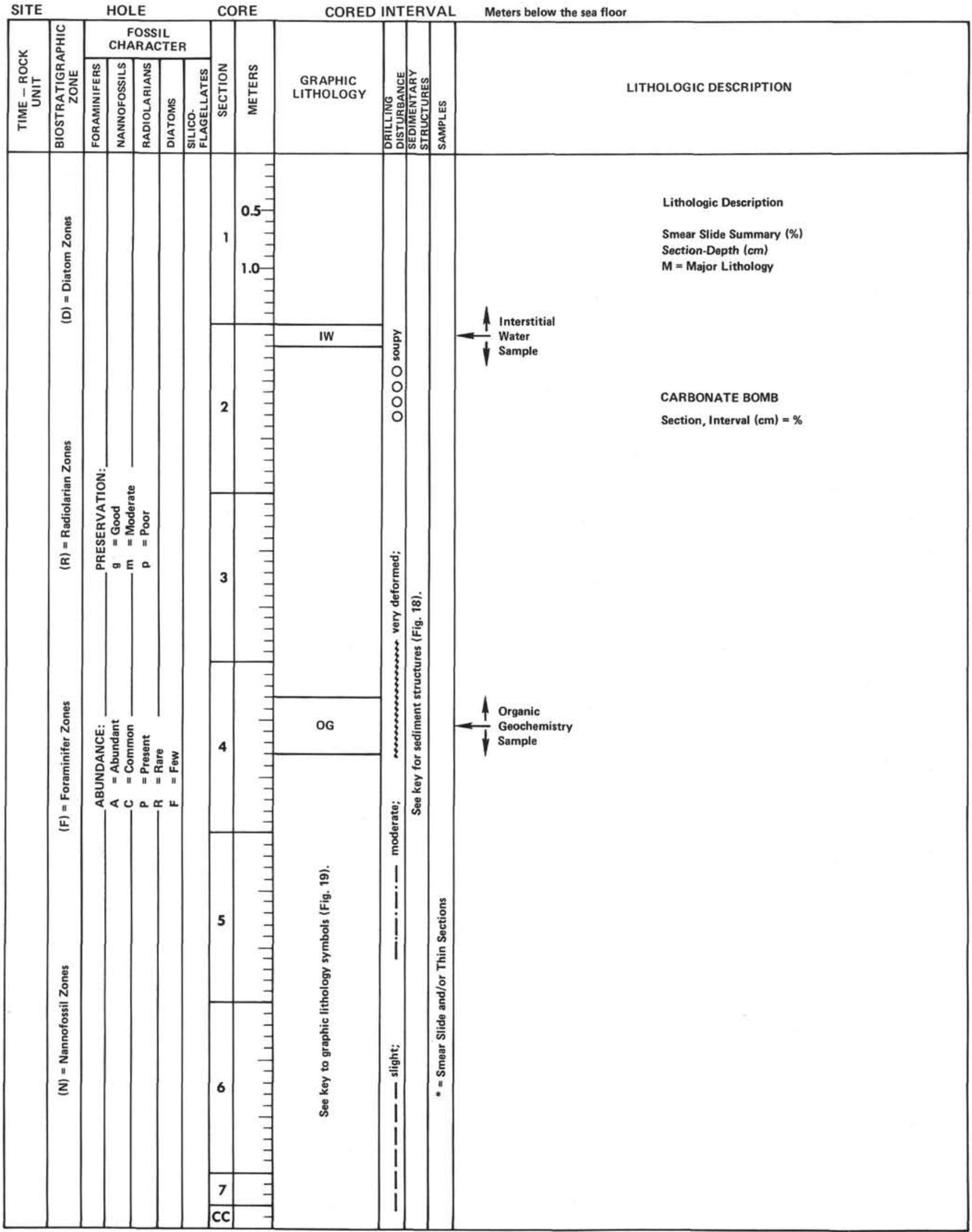

Figure 16. Sample core form (sediment). 


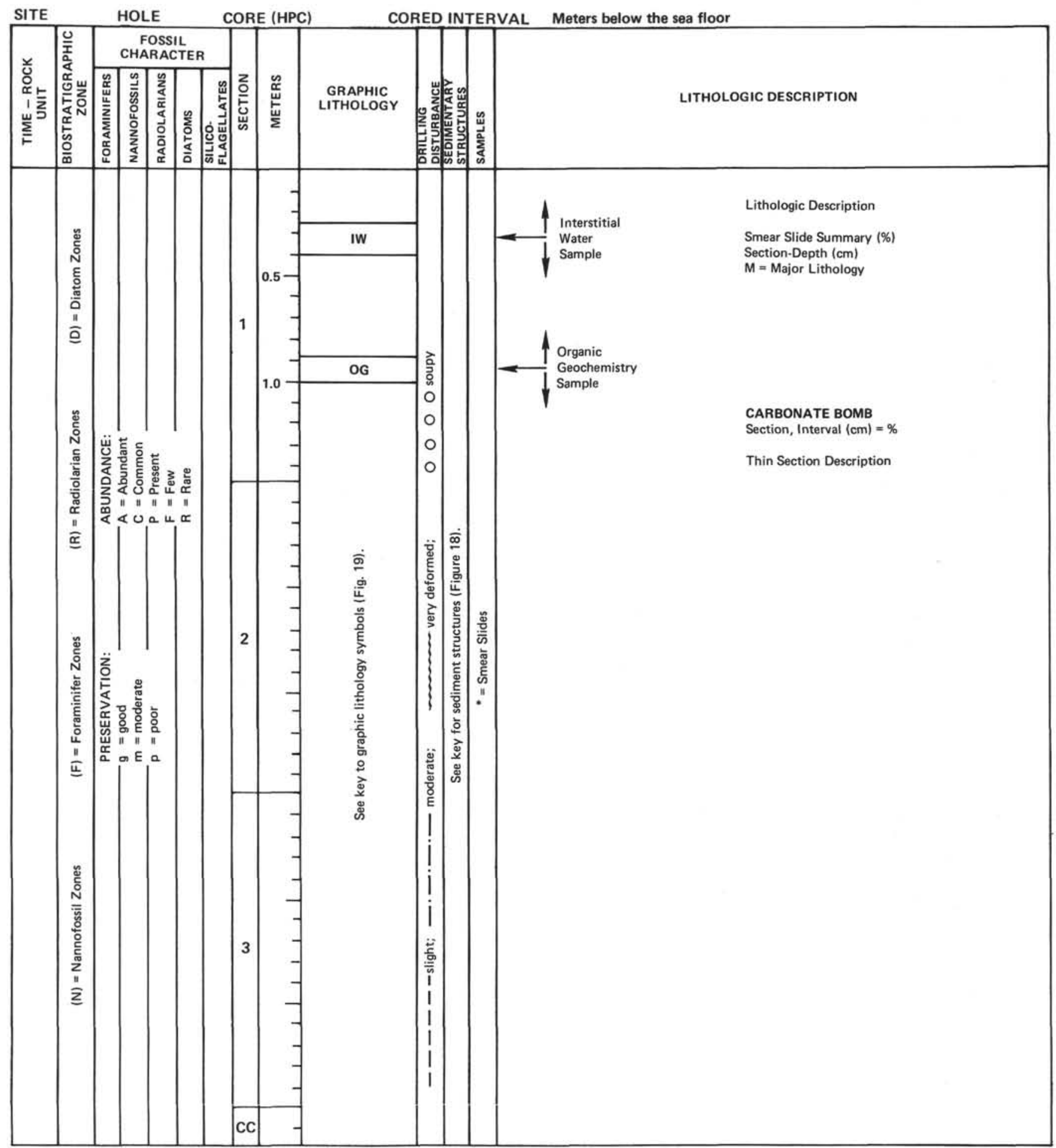

Figure 17. Sample core form (sediment, hydraulic piston cored).

silt-sized terrigenous particles (e.g., quartz and feldspar) than a nannofossil silty clay simply because many diatoms are silt sized and are included as such in the textural estimate. However, we have chosen fairly broad compositional class boundaries for mixed terrigenous and biogenic sediments (see below) in order to minimize this effect. For this reason we preferred to replace "clayey-silt" or "silty-clay" by "mud" in combination with a biogenic modifier.
We used as many modifiers as necessary to describe the type of sediment encountered. In all cases the dominant component appears last in the name; minor components precede, with the least common constituent listed first. Constituents that occur in amounts less than $10 \%$ are not included in the name. This convention also holds for zeolites, $\mathrm{Fe}$ - and $\mathrm{Mn}$-micronodules, and other indicators of very slow rates of sedimentation or nondeposition, such as fish teeth. Often 
Recommended Symbol

Description

\begin{tabular}{|c|c|}
\hline $\mathrm{mm}$ & Current ripples \\
\hline 管 & Micro-cross-laminae (including climbing ripples) \\
\hline & Parallel bedding \\
\hline$\sim$ & Wavy bedding \\
\hline & Flaser bedding \\
\hline - & Lenticular bedding \\
\hline & Cross-stratification \\
\hline & Slump blocks or slump folds \\
\hline & Load casts \\
\hline$\circlearrowleft$ & Scour \\
\hline 000 & Normal graded bedding \\
\hline & Reversed graded bedding \\
\hline NeES & Convolute and contorted bedding \\
\hline II & Water escape pipes \\
\hline var & Mud cracks \\
\hline & Sharp contact \\
\hline w & Scoured, sharp contact \\
\hline & Disturbed sharp contact \\
\hline- & Gradational contact \\
\hline & Imbrication \\
\hline & Fining-upward sequence \\
\hline & Coarsening-upward sequence \\
\hline & Interval over which a specific structure occurs in core \\
\hline ? & Bioturbation $-\operatorname{minor}(0-30 \%$ surface area) \\
\hline 3 & Bioturbation-moderate $(30-60 \%$ surface area) \\
\hline in & Bioturbation-strong (more than $60 \%$ of surface area) \\
\hline$\infty$ & Burrows \\
\hline e & Gastropod shell \\
\hline
\end{tabular}

Figure 18. Symbols used to identify sedimentary structures on core description forms.

these minerals are conspicuous even though greatly diluted, and they are sometimes included in the name of the sediment or mentioned in the lithologic description.

Induration of sediments. We recognize three classes of induration or lithification for calcareous sediments and sedimentary rocks (sedi- ments and rocks in which the carbonate content is greater than 50\%) and only two classes for all other lithologic types.

1. Calcareous sediments and sedimentary rocks (categories after Gealy et al., 1971):

a. Soft $=$ ooze; has little strength and is readily deformed under the pressure of a finger or the broad blade of spatula.

b. Firm = chalk; partially lithified and readily scratched with a fingernail or the edge of spatula.

c. Hard = limestone or dolostone; well lithified and cemented, resistant or impossible to scratch with a fingernail or the edge of a spatula.

2. Siliceous sediments (silica $>50 \%$ ):

a. Soft $=$ ooze; readily deformed by a finger or the broad blade of a spatula.

b. Hard = radiolarite, diatomite, chert, or porcellanite; core must be cut with a band saw or a diamond saw.

3. Terrigenous sediments (terrigenous components $>50 \%$ ):

a. Soft $=$ sand, silt, clay (or combinations of these); readily deformed by a finger or the broad blade of spatula.

b. Hard = sandstone, siltstone, claystone, etc. (i.e., suffix "stone" added); core must be cut with a band saw or a diamond saw.

\section{Types of Sediment and Compositional Class Boundaries}

We distinguish five basic types of sediment: siliceous biogenic sediments, calcareous biogenic sediments, terrigenous sediments, volcanogenic and pyroclastic sediments, and hemipelagic sediments. Each type of sediment is discussed briefly below.

Siliceous biogenic sediments. These are sediments in which biogenic silica or authigenic silica (opal-CT and/or quartz) makes up at least $30 \%$ of the sediment. If the siliceous component is between 30 and $60 \%$, the terrigenous (mud) calcareous biogenic or volcanogenic modifier is retained. For example, muddy diatomaceous ooze describes a soft sediment with at least $10 \%$ clayey silt and between 50 and $90 \%$ diatoms. If the siliceous component exceeds $60 \%$, the modifier(s) are dropped. A radiolarian ooze would have $<10 \%$ clay or carbonate and $>60 \%$ radiolarians. If the siliceous biogenic component is between 30 and $60 \%$, the names for terrigenous or calcareous biogenic sediments or pyroclastic rocks apply, with the dominant siliceous constituent as a qualifier. Silica in amounts $<10 \%$ is not acknowledged in the name.

For hard siliceous rocks, siliceous microfossils are often absent. If they have been dissolved and replaced by opal-CT and/or quartz and these minerals make up $>50 \%$ of the rock, the terms chert and porcellanite apply. Chert is defined as a hard, conchoidally fractured varicolored sedimentary rock that has a semivitreous, vitreous, or waxy luster and that consists primarily of silica. Porcellanite is defined as a siliceous sedimentary rock that has a dull or matte luster that resembles that of unglazed porcelain. It is less hard, dense, and vitreous than chert and commonly has a lower silica content. These definitions differ from previous DSDP usage in that chert and porcellanite are textural terms independent of the silica polymorph present. If two modifiers are used, the order of the two modifiers in the terms depends on the dominant fossil type. The most dominant component is listed last and the minor component is listed first.

Calcareous biogenic sediments. These are sediments in which biogenic carbonate or carbonate of indeterminate origin (cement or recrystallized carbonate) makes up at least $30 \%$ of the sediment. If the carbonate component is between 30 and $60 \%$, the terrigenous, siliceous biogenic, or volcanogenic modifiers are retained. For example, muddy nannofossil ooze describes a soft sediment with at least $10 \%$ clay and between 30 and $60 \%$ calcareous nannofossils. If the calcareous component exceeds $60 \%$, the modifiers are dropped. A nannofossil ooze would have $<10 \%$ clay or silica and $60 \%$ calcareous nannofossils. If the calcareous biogenic component is between 30 and $60 \%$, the names for terrigenous or siliceous biogenic sediments or pyroclastic rocks apply, with the dominant calcareous constituent as a qualifier. Carbonate less than $10 \%$ is not acknowledged in the name.

For firm and hard calcareous rock with carbonate contents $>50 \%$, the terms chalk, limestone, and dolostone, respectively, apply. If the carbonate content is between 30 and $60 \%$ the terrigenous modifier is retained. The modifiers are dropped when the carbonate content exceeds $60 \%$. If the carbonate content is less than $30 \%$, the terrigenous 


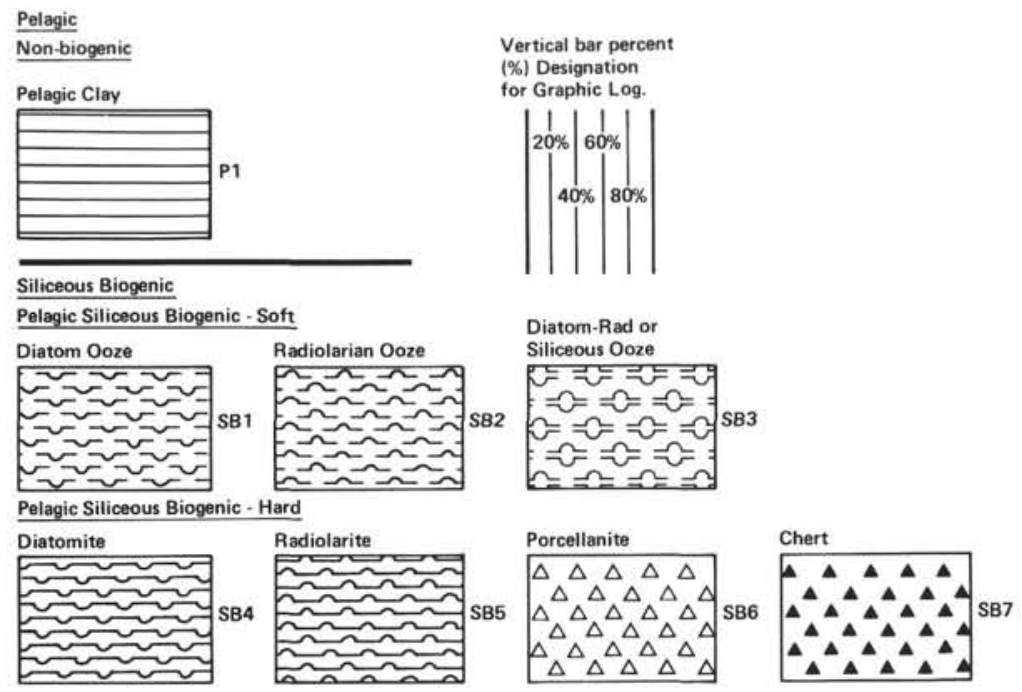

Transitional Siliceous Terrigenous Sediments

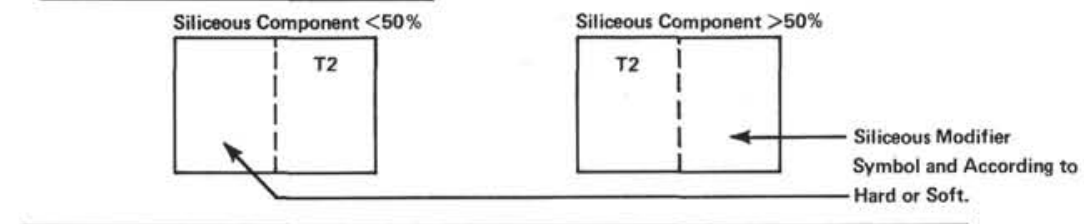

Siliceous Component $>50 \%$

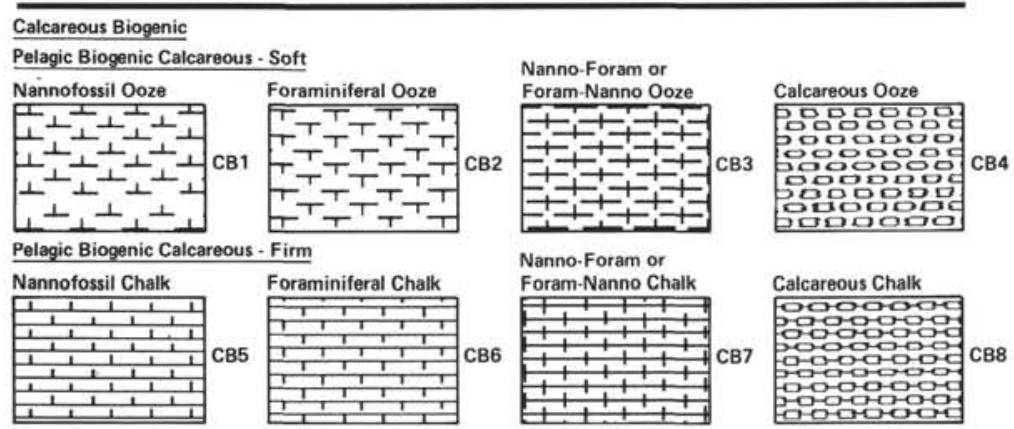

Burrows:

$P \quad=$ Planolites

$Z$ = Zoophycus

$\mathrm{H}=$ Halo

$\mathrm{C}=$ Chondrites

Pelagic Biogenic Calcareous - Hard

Limestone

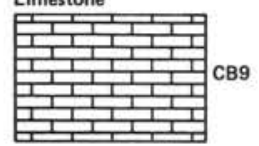

Terrigenous Sediments

Clay/Claystone

Qualifiers Letter Overprint (as per examples)

Zeolite A1 GIaconite A3

Siderite A4 (other may be designated)

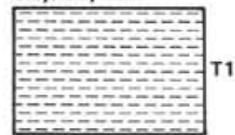

Mud/Mudstone

Shale (Fissile) Sandy Mud/Sandy Mudstone Silt/Siltstone

be designated)
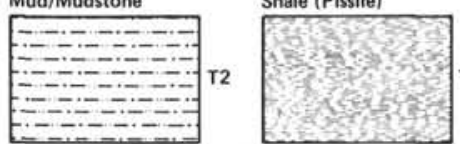

T3 T4

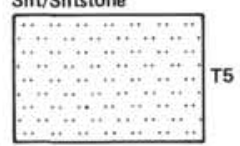

T5
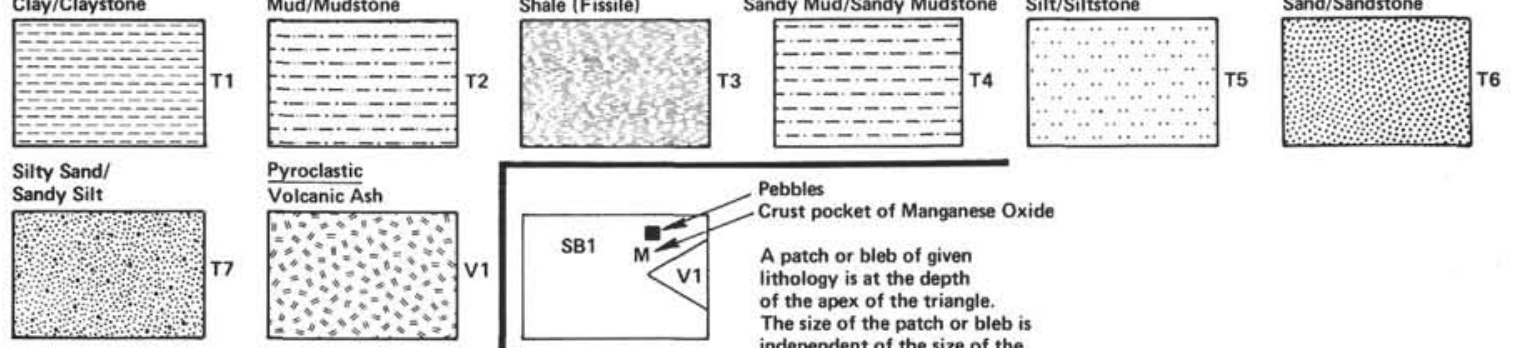

Pyroclastic

Volcanic Ash

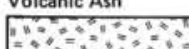

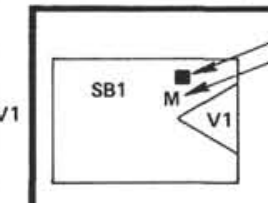

Pebbles

Crust pocket of Manganese Oxide

A patch or bleb of given

lithology is at the depth

of the apex of the triangle.
The size of the patch or bleb is

The size of the patch or bleb is
independent of the size of the

triangle.

Figure 19. Symbols used to identify lithology on sediment core description forms (Figs. 16 and 17).

siliceous biogenic, or volcanogenic names apply, with the dominant carbonate type retained as a qualifier. Carbonate is not acknowledged in the name if it is present in amounts $<10 \%$.

Terrigenous sediments. Terrigenous components at Sites 501, 504, and 505 are in a variable clay fraction encompassed in the previous description for calcareous biogenic sediments.
Volcanogenic and pyroclastic sediments. We arbitrarily distinguish pyroclastic rocks from volcanogenic sediments by using $50 \%$ as the pivotal percentage, pyroclastic rocks having $>50 \%$ volcanic components, volcanogenic sediments $<50 \%$. The Wentworth and Williams (1932) textural and compositional classification applies for the pyroclastic rocks. The only textural group applicable to our sediments is 

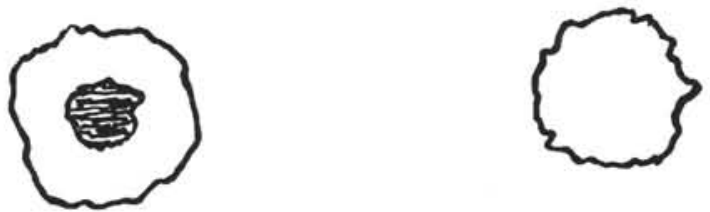

Hollow Cylindrichnus

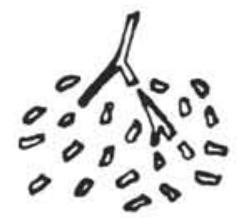

Chondrites

\section{DDDDDDDDDDDDDDDD}

Simple Zoophycos

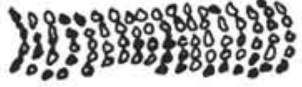

Pelleted Zoophycos
Solid Cylindrichnus

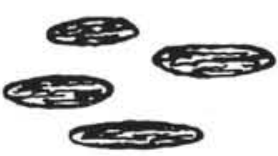

Planolites

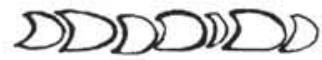

Fat Zoophycos

Pyrite Burrows

Figure 20. Most common trace fossils in Deep Sea Drilling Project cores.

$<4 \mathrm{~mm}$ (volcanic ash). The ashes were all glassy and rhyolitic as determined by XRF chemical analysis.

Other sediments. No hemipelagic or special sediment types were recovered at Site 501,504 , or 505 .

\section{Special Studies of Sediments}

\section{Biostratigraphy}

The biostratigraphy for Sites 501, 504, and 505 is based upon diatom datum levels. Burckle $(1977,1978)$ has correlated these events with paleomagnetic boundaries in several sites of the central and eastern equatorial Pacific. It is thus possible to give an estimate of absolute age for each datum (Fig. 21). The scheme used here differs from the work referenced above in the addition of two new species (Burckle et al., 1978; Burckle and Trainer, 1979) and the absence of species and datums found to be unreliable because of rarity or apparent time transgression.

Figure 21 illustrates the biostratigraphic system used in this report. Ages of magnetic boundaries (which were analyzed by D. Kent) were based upon recent revisions in the decay constant of potassium. For convenience, the Pleistocene and Pliocene are informally divided into early and late intervals at the Brunhes/Matuyama and the Gauss/ Gilbert boundaries. Diatom zones are those of Burckle (1972).

On the barrel sheets, the diatom zones are given in the column for Biostratigraphic Zone, while the events (which are more numerous) are indicated by an arrow under Diatom Fossil Character. Estimates of the abundance and preservation of diatoms and calcareous nannofossils are based on smear slide analysis; for foraminifera and radiolaria estimates are based on the washed coarse fraction $(>63 \mu \mathrm{m})$

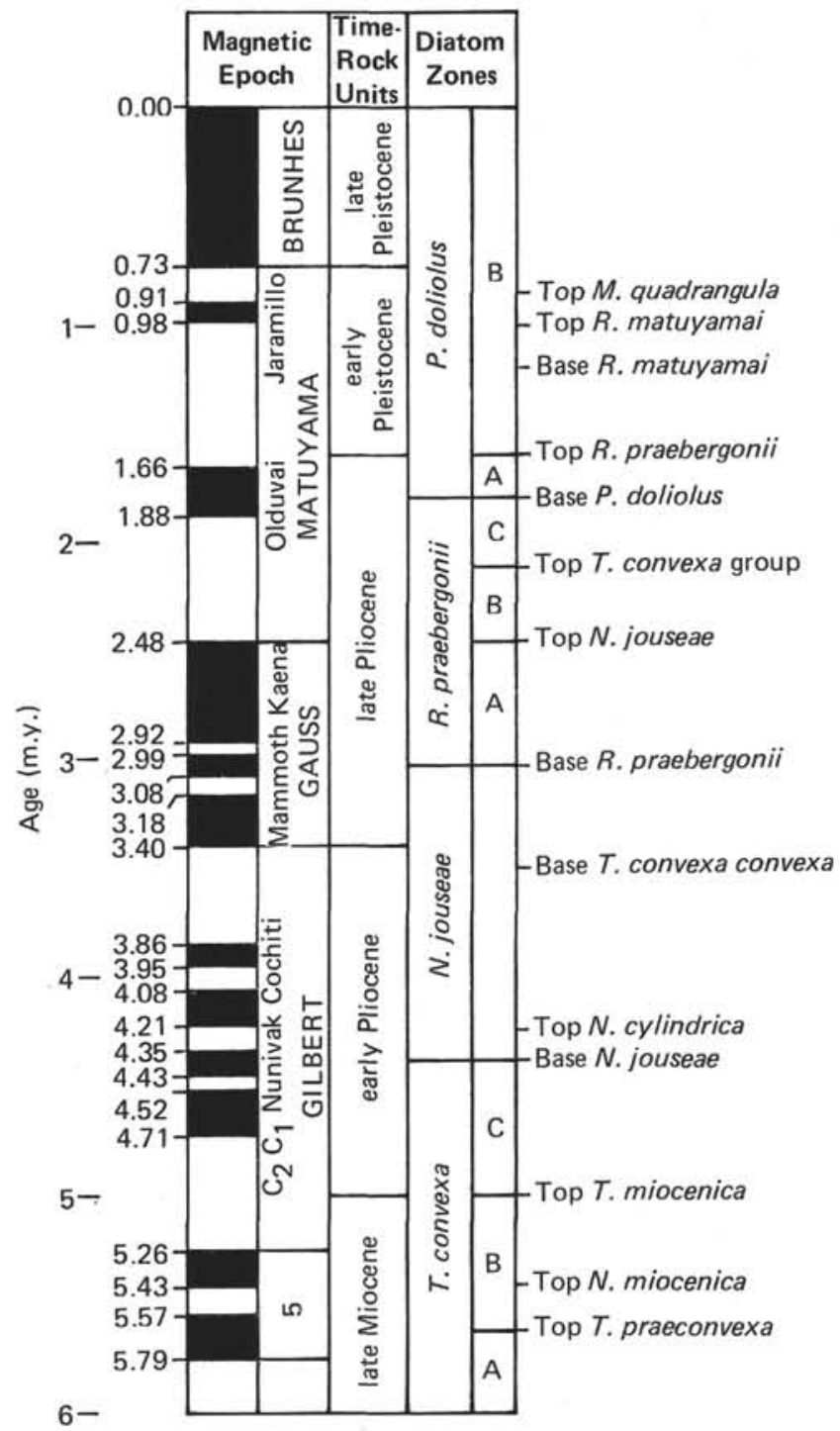

Figure 21. Diatom datum levels calibrated to magnetic epoch and estimated absolute age. A, B, C denote diatom subzones.

from the core catchers. $\mathrm{A}=$ abundant $(60 \%$ of all sediment components), $\mathrm{C}=$ common $(40-60 \%), \mathrm{P}=$ present $(20-40 \%), \mathrm{F}=$ few $(5-20 \%)$ and $\mathrm{R}=$ rare $(5 \%) ; \mathrm{g}=$ good preservation (no dissolution), $\mathrm{m}=$ moderate preservation (some dissolution and fragmentation), $\mathrm{p}=$ poor preservation (dissolution and fragmentation high, overgrowth on discoasters).

Igneous Rocks

\section{Visual Core Description Forms}

All igneous rocks were split by using a rock saw into working and archive halves and described on board. Figure 22 shows a composite visual core description form used for the description of the igneous rocks recovered on Leg 70. Each section of core is described on this form under five columns: piece number, graphic representation, orientation, shipboard studies, and alteration.

In the graphic representation column each piece is accurately drawn, as well as such features as texture, glassy margins, and the location of styrofoam spacers taped between pieces inside the liner. Each piece is numbered consecutively for the entire leg from the top of the first section, beginning with the number 1 and continuing in order to the piece of igneous rock recovered at the end of the leg. Spacers were placed only between pieces that did not fit together: pieces were 
N

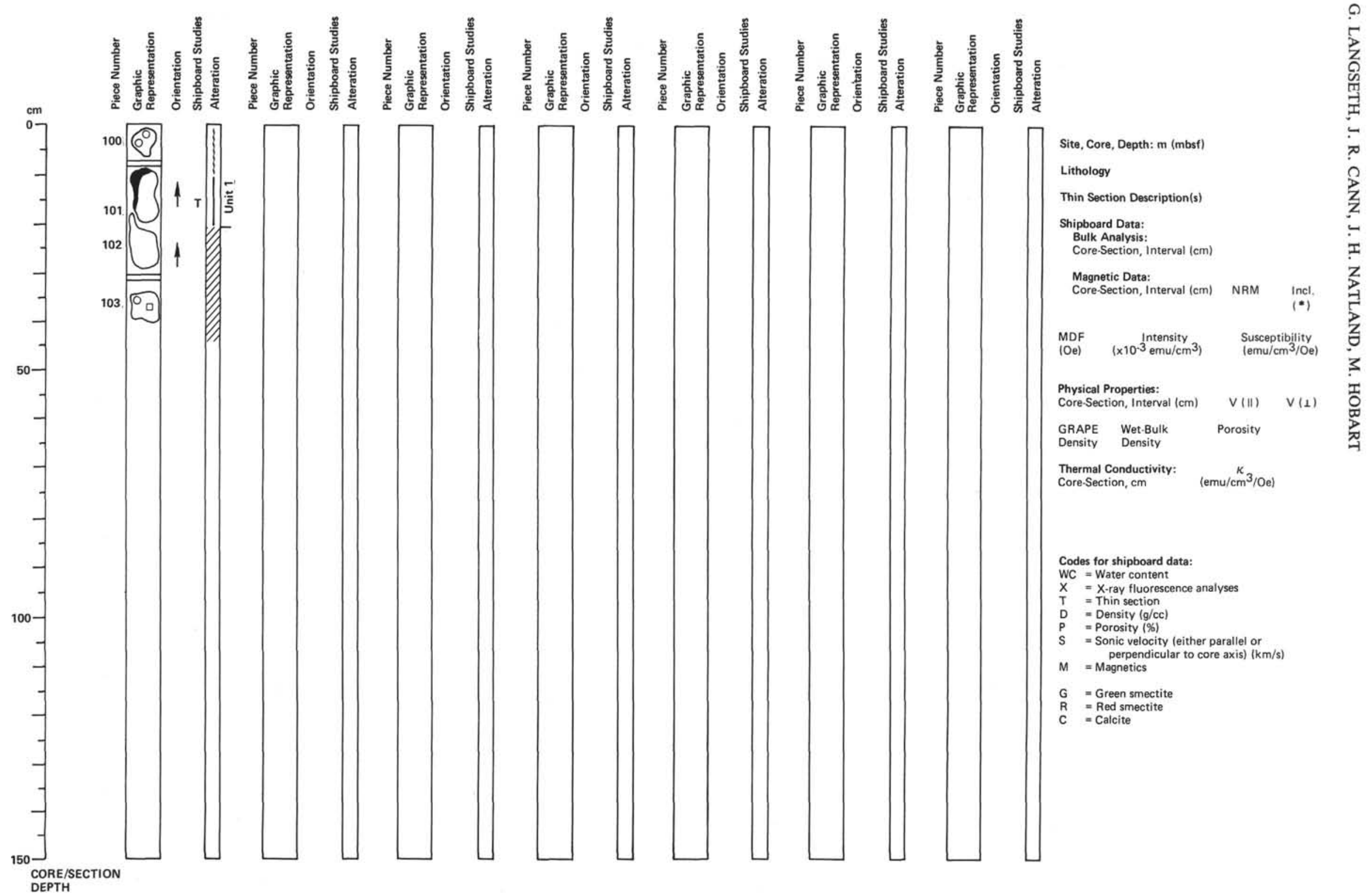

Figure 22. Visual core description form for igneous rocks. 
numbered sequentially starting with 1 for both Legs 69 and 70 regardless of hole, core, or site. Spacers may or may not indicate missing material (not recovered) between pieces. All cylindrical pieces longer than the diameter of the liner have arrows in the "orientation" column indicating that top and bottom could not have been reversed as a result of drilling recovery. Arrows also appear on the labels of these pieces on both archive and working halves.

The column marked "Shipboard Studies" is used to indicate the location and the type of measurements made on a sample on board. The column headed "Alteration"' gives the degree of alteration by using the code given in Figure 23. Below each set of five columns is the designation for core and section for which the data apply.

An outline of further information on the igneous rocks appears in the right-hand margin of the visual core description form (Fig. 22). For each core, the core number, sections, and depth interval recovered are listed, followed by the major and minor rock types and a short description. Thin section data are tallied below this, then shipboard data. If more than one core appears on a single core form some of the information is listed below the description of the first core. As many cores as space allows are included on one visual core description form. When space for descriptions is inadequate on this form, the data appear on the following or facing page. However, in no case does information from one core appear on more than one core form.

Because alteration minerals were abundant, we indicated their occurrence and type based on color by using the letter G (green) and R (red) immediately to the right of the alteration column. Carbonate minerals (calcite aragonite) were indicated by the letter $\mathrm{C}$.

\section{Classification of Igneous Rocks}

We classified igneous rocks informally according to mineralogy and texture as determined from the visual inspection of hand specimens and thin sections. The following conventions were agreed upon while at sea, and we realize that they are generalized. Gradations may exist within and among textural groups in a single sample.
TEXTURE

Used in graphic representation column

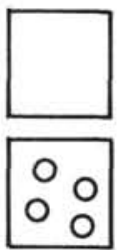

Aphyric basalt

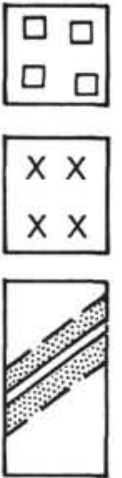

Porphyritic basalt

Plagioclase

phenocrysts

Clinopyroxene

phenocrysts

Vein with altered zone next to it

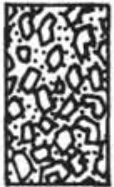

Breccia

(as graphic

as possible)

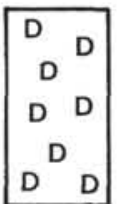

Dolerite

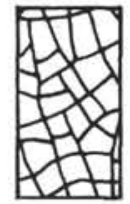

Fractures
WEATHERING: ALTERATION

Used in alteration column

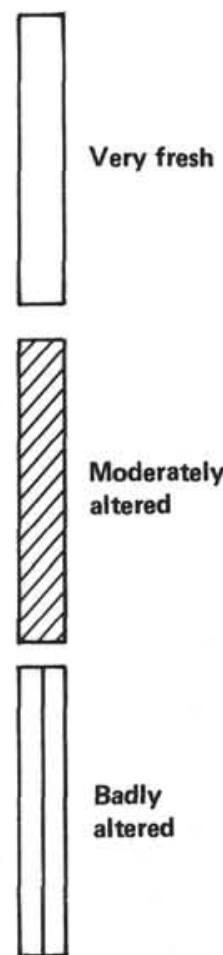

Weathered rind

on rounded

piece

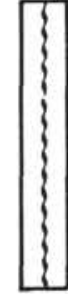

Almost completely

altered

\section{Moderately}

altered

(slight discoloration)

but has fresh core or

is partly fresh

Figure 23. Symbols used to describe igneous rocks drilled during Legs 68,69 , and 70 . 
A. Quench textures recognized and described include:

1. Glassy-matrix is amorphous basaltic glass with no visible incipient crystallization.

2. Variolitic or spherulitic-texture is characterized by the presence of variolites or spherulites (spherical bodies that usually consist of radiating plagioclase and/or clinopyroxene microlites or crystals); individual crystals cannot be distinguished with the microscope.

3. Subvariolitic or subspherulitic-texture in which varioles coalesce.

4. Immature sheaf - a bundled arrangement of small crystals (which cannot be individually distinguished with the microscope) that assume a sheaflike appearance; a central axis of crystal growth often occurs.

5. Mature sheaf-same as above, but discrete skeletal crystals can be distinguished with the microscope (they are usually greater than $0.005 \mathrm{~mm}$ wide).

6. Plumose-plume- or featherlike arrangement of microlites or crystals; they may grade from immature to mature (as in sheaf texture) because of crystal size.

B. Major textural classification for basaltic samples used during Leg 70 include:

1. Phyric-a term applied to igneous rocks in which larger crystals (phenocrysts) are set in a finer groundmass which may be crystalline or glassy, or both.

Aphyric: no phenocrysts

Sparsely phyric: $1-2 \%$ pheriocrysts

Moderately phyric: $2-10 \%$ phenocrysts

Highly phyric: more than $10 \%$ phenocrysts

2. Glomerophyric-a term applied to phyric igneous rocks that contain clusters of equant crystals larger than the matrix crystals.

3. Ophitic-a term applied to igneous rocks in which euhedral or subhedral crystals of plagioclase are embedded in a mesostasis of pyroxene crystals.

4. Subophitic-a term applied to the texture of an ophitic igneous rock in which the feldspar crystals are approximately the same size as the pyroxene crystals and are only partially included by them.

5. Intergranular-a term applied to igneous rocks in which there is an aggregation of grains of clinopyroxene, not in parallel optical continuity (as in subophitic texture), between a network of feldspar laths, which may be diverse, subradial or subparallel. Distinguished from an intersertal texture by the absence of interstitial glass or other quenched places that fill the interstices between the feldspar laths.

6. Intersertal-a term applied to volcanic rocks wherein a base of mesostasis or glass and sma!l crystals fill the interstices between unoriented feldspar laths, the base forming a relatively small proportion of the rock. When the amount of the base increases and the feldspar laths decrease, the texture becomes hyalophitic. With a still greater increase in the amount of the base, the texture becomes hyalopilitic.

\section{Physical Properties}

Boyce (1976) describes in considerable detail the equipment, methods, and corrections routinely used by shipboard scientists to measure the physical properties of sediments and rocks recovered at deep sea drilling sites. On Leg 70 we determined saturated bulk density by using the gamma ray attenuation porosity evaluator and the gravimetric technique porosity calculated from GRAPE and gravimetric measurements, water content from gravimetric measurements, and sonic velocity using the Hamilton frame velocity meter. For GRAPE density and porosity calculations we assume grain densities of $2.70 \mathrm{~g} / \mathrm{cc}$ for sediments and $2.90 \mathrm{~g} / \mathrm{cc}$ for igneous rocks and a corrected pore fluid density of $1.128 \mathrm{~g} / \mathrm{cc}$. Thermal conductivities were measured using the Vacquier flat plat sensor. Physical properties data are listed on the basalt description sheets.

\section{REFERENCES}

Allmendinger, R. W., and Riis, F., 1979. The Galapagos Rift at $86^{\circ} \mathrm{W}, 1$ : regional morphological and structural analysis. J. Geophys. Res., 84:5379-5389.
Anderson, R. N., and Hobart, M. A., 1976. The relation between heat flow, sediment thickness, and age in the eastern Pacific. J. Geophys. Res., 81:2968-2989.

Bowles, F. A., Fack, R. N., and Carmichael, I. S. E., 1973. Investigation of deep-sea volcanic ash layers from equatorial Pacific cores. Geol. Soc. Am. Bull., 84:2371-2388.

Boyce, R. E., 1976. Definitions and laboratory techniques of compressional sound velocity parameters and wet-water content, wetbulk density, and porosity parameters by gravimetric and gamma ray attenuation techniques. In Schlanger, S. O., Jackson, E. D., et al., Init. Repts. DSDP, 33: Washington (U.S. Govt. Printing Office), 931-958.

Burckle, L. H., 1972. Late Cenozoic planktonic diatom zones from the eastern Equatorial Pacific. Nova Hedwigia, 39:217-246.

1977. Pliocene and Pleistocene diatom datum levels from the equatorial Pacific. Quat. Res., 7:330-340.

1978. Early Miocene to Pliocene datum levels for the equatorial Pacific. Geol. Res. Develop. Centre, Republic of Indonesia, Spec. Publ., 1:25-44.

Burckle, L. H., and Trainer, J., 1979. Middle and late Pliocene diatom datum levels from the central Pacific. Micropaleontology, 25:281-293.

Christensen, N. I., and Salisbury, M. H., 1975. Structure and composition of the lower oceanic crust. Rev. Geophys. Space Phys., 13:57-86.

Corliss, J. B., Dymond, J. R., Gordon, L. I., Edmond, J. M., Von Herzen, R. P., Ballard, R. D., Green, K., Williams, D. L., Bainbridge, A., Crane, K., and van Andel, Tj. H., 1979. Submarine thermal springs on the Galapagos Rift. Science, 203:1073-1083.

Corliss, J. B., Gordon, L. I., and Edmond, J. M., 1979. Some implications of heat/mass ratios in Galapagos Rift hydrothermal fluids for models of sea-water rock interaction and the formation of oceanic crust. In Talwani, M., Harrison, C. G., and Hayes, D. E., (Eds.), Deep Drilling Results in the Atlantic Ocean: Ocean Crust: Washington (Am. Geophys. Union), Maurice Ewing Series 2: 391-402.

Crane, K., 1978. Structure and tectonics of the Galapagos inner rift, $86^{\circ} 10^{\prime}$ W. J. Geol., 86:715-730.

CRRUST, 1982. Geothermal regimes of the Costa Rica Rift, East Pacific, investigated by drilling, DSDP-IPOD Legs 68,69 and 70. Geol. Soc. Am. Bull., 93:862-875.

Gealy, E. L., Winterer, E. L., and Moberly, R. M., Jr., 1971. Methods, conventions, and general observations. In Winterer, E. L., Riedel, W. R., et al., Init. Repts. DSDP, 7, Pt. 1: Washington (U.S. Govt. Printing Office), 9-26.

Green, K. E., Von Herzen, R. P., and Williams, D. L., 1981. The Galapagos Spreading Center at $86^{\circ} \mathrm{W}$ : a detailed geothermal field study. J. Geophys. Res., 86:979-986.

Hekinian, R., Rosendahl, B. R., and Natland, J. H., 1980. Ocean crust geothermal processes: a perspective from the vantage of Leg 54 drilling. In Rosendahl, B. R., Hekinian, R., et al., Init. Repts. $D S D P, 54$ : Washington (U.S. Govt. Printing Office), 395-422.

Hey, R. N., 1977. Tectonic evolution of the Cocos-Nazca spreading center. Geol. Soc. Am. Bull., 88:1404-1420.

Hey, R. N., and Vogt, P. R., 1977. Rise axis jumps and sub-axial flow near the Galapagos hot spot. Tectonophysics, 37:41-52.

Honnorez, J., Von Herzen, R. P., et al., in press. Init. Repts. DSDP, 70: Washington (U.S. Govt. Printing Office).

Houtz, R., and Ewing, J., 1976. Upper crustal structure as a function of plate age. J. Geophys. Res., 81:2490-2498.

Hyndman, R. D., Von Herzen, R. P., Erickson, A. J., and Jolivet, J., 1977. Heat flow measurements DSDP Leg 37. In Aumento, F., Melson, W. G., et al., Init. Repts. DSDP, 37: Washington (U.S. Govt. Printing Office), 347-362.

Klitgord, K. D., Mudie, J. D., Huestis, S. P., and Parker, R. L., 1975. An analysis of near-bottom magnetic anomalies: sea-floor spreading and the magnetized layer. Geophys. J. R. Astron. Soc., 43: 387-424.

Langseth, M. G., and Herman, B. M., 1981. Heat transfer in the oceanic crust of the Brazil basin. J. Geophys. Res., 68:10,80510,819 .

Lister, C. R. B., 1972. On the thermal balance of a mid-ocean ridge. Geophys. J. R. Astron. Soc., 26:575-535. 
Lonsdale, P., 1977. Deep-tow observations at the mounds abyssal hydrothermal field, Galapagos Rift. Earth Planet. Sci. Lett., 36: 92-110.

Lonsdale, P., and Klitgord, K. D., 1978. Structure and tectonic history of the eastern Panama Basin. Geol. Soc. Am. Bull., 89: 981-999.

Müller, G., and Gastner, M., 1971. The "Karbonat Bombe," a simple device for the determination of the carbonate content in sediments, soils, and other materials. N. Jahrb. Mineral. Mh., 10: 466-469.

Natland, J. H., and Rosendahl, B. R., 1980. Drilling difficulties in basement during Deep Sea Drilling Project Leg 54. In Rosendahl, B. R., Hekinian, R., et al., Init. Repts. DSDP, 54: Washington (U.S. Govt. Printing Office), 593-603.

Ninkovich, D., and Shackleton, N. J., 1975. Distribution, stratigraphic position, and age of ash layer "L" in the Panama Basin region. Earth Planet. Sci. Lett., 27:20-34.

Rosendahl, B. R., Hekinian, R., et al., 1980. Init. Repts. DSDP, 54: Washington (U.S. Govt. Printing Office).
Ross, D. A. Neprochnov, Y. P., et al., 1978. Init. Repts. DSDP, 42, Pt. 2: Washington (U.S. Govt. Printing Office).

Stephen, R. A., Louden, K. E., and Matthews, D. H., 1980. The oblique seismic experiment on Deep Sea Drilling Project Leg 52. In Donnelly, T., Francheteau, J., Bryan, W., Robinson, P., Flower, M., Salisbury, M., et al., Init. Repts. DSDP, 51, 52, 53, Pt. 1: Washington (U.S. Govt. Printing Office), 675-704.

Wentworth, C. K., and Williams, H., 1932. The classification and terminology of the pyroclastic rocks. Rept. Comm. Sedimentation, Bull. Nat. Res. Counc., 80:10-53.

Williams, D. L., Green, K., van Andel, Tj. H., Von Herzen, R. P., Dymond, J., and Crane, K., 1979. The hydrothermal mounds of the Galapagos Rift: observations with DSRV Alvin and detailed heat flow studies. J. Geophys. Res., 84:7467-7484.

Williams, D. L., Von Herzen, R. P., Sclater, J. G., and Anderson, R. L., 1974. The Galapagos Spreading Centre: lithospheric cooling and hydrothermal circulation. Geophys. J. R. Astron. Soc., 38: $587-608$.

Worzel, J. L., 1959. Extensive deep sea sub-bottom reflections identified as white ash. Proc. Nat. Acad. Sci., 45:349-355. 